ISSN 2466-2232 (Print)

ISSN 2466-2100 (Online)

\title{
A Review on Welding of Dissimilar Metals in Car Body Manufacturing
}

\author{
Md. Abdul Karim* and Yeong-Do Park*, ${ }^{*}$ \\ *Department of Advanced Materials Engineering, Dong-Eui University, Busan, 47340, Korea \\ †Corresponding author : ypark@deu.ac.kr \\ (Received December 20, 2019 ; Revised February 4, 2020 ; Accepted February 17, 2020)
}

\begin{abstract}
This paper presents a comprehensive study of the metallurgical challenges of welding dissimilar metals. It also describes the important factors in dissimilar welding which need to be considered for automotive applications. It further investigates effective approaches to overcome these present challenges. Steels, aluminum alloys, and magnesium alloys are widely used metals in car bodies. However, it is difficult to weld these dissimilar metals and achieve good joint quality, due to their inherent disparate properties. The formation of brittle, crack sensitive and corrosion susceptible intermetallic phases is the main obstacle to dissimilar weld quality. Various approaches have been attempted by many researchers to enhance the performance of dissimilar welds. The most notable efforts include the application of interlayers, cover plate, least heat input, a combination of welding and mechanical joining, and alloying elements of filler metals. Based on considerations of joint performance, production cost and time, present industry infrastructure, and so on, the most effective and feasible approaches were identified which required the least amount of heat input, and the appropriate filler metal alloying elements.
\end{abstract}

Key Words : Review, Dissimilar metals, Welding, Car body, Steels, Aluminum, Magnesium, Intermetallics

\section{Introduction}

In present environmental issues, the reduction of $\mathrm{CO}_{2}$ emissions is a major concern for the automotive industries ${ }^{1}$. Automotive manufacturers are trying to reduce vehicle weight in order to minimize fuel consumption and emissions. Generally, a typical car body contributes approximately $30 \%$ of the total weight of a $\mathrm{car}^{2}$, and about $10 \%$ weight reduction of a car results in $5.5 \%$ improvement in fuel economy ${ }^{3,4)}$. Consequently, the application of lightweight materials for car body manufacturing has been highly promising to reduce vehicle weight. Car body manufacturing needs lightweight materials which also can ensure high mechanical performance and satisfactory protection from corrosion ${ }^{5)}$. Since no single available material can satisfy all these requirements, a variety of dissimilar materials combination is applied. In 2005, the project named as SuperLIGHT- CAR (SLC) was initiated by 38 leading European organ- izations for weight reduction of a compact class passenger car body. The project aimed to reduce the weight of body-in-white (BIW) by at least $30 \%$ through the application of multi-material structures ${ }^{6}$. Fig. 1 presents the weight and material distribution of the final concept of the SLC project. It seems that automotive industries have been very keen to replace conventional steels with lightweight materials, such as aluminum alloys, magnesium alloys, advanced high strength steels, and composites.

Though multi-materials integration has great importance in car body manufacturing, but the joining of different materials is very challenging because of their inherent disparate properties. Furthermore, the technological, economic, and ecological factors need to be carefully considered for the joining processes ${ }^{8)}$. In dissimilar metal welding, the mutual solid solubility and the formation of the intermetallics are significantly influenced by welding process ${ }^{9}$. The formation of a weak and brittle intermetallic zone is the main drawback. The intermetallic zone formed in dissimilar metal welding is

Journal of Welding and Joining, Vol.38 No.1(2020) pp8-23

https://doi.org/10.5781/JWJ.2020.38.1.1 
highly susceptible to cracks and corrosion ${ }^{10)}$. The thermal cycle of the welding process changes the properties of the weld zone and adjacent base metals. The difference in thermal properties of dissimilar metals induces the thermal stresses and forms cavities and cracks. Moreover, dissimilar metal welds form galvanic couples and may initiate galvanic corrosion in aggressive environments. The formation of thick intermetallic compounds (IMCs) layer in dissimilar metal welds can increase the possibility of cracks formation and the corrosion rate. Therefore, the thickness of the intermetallics layer can be considered as one of the important quality indexes for mechanical and corrosion performance of dissimilar metal welds. The controlling or reducing of intermetallics formation is the key factor to achieve a good weld quality. This paper aims to focus on the metallurgical challenges in dissimilar metal welding and systematically presents the key aspects of various approaches attempted by many researchers to reduce the brittle intermetallics in the welds. It also describes the important factors of dissimilar metal welding that needs to be considered for automotive applications, and investigates the most feasible approaches to overcome the present challenges.

\section{Materials in Car Body}

Material selection is one of the most important stages of the vehicle design. Several important factors including lightweight, safety, durability, manufacturability, recyclability, environmental effects, and economic issues must be considered for proper material selection. Steels, aluminum alloys, magnesium alloys, and fiber-reinforced composites are the mostly applied materials in car body production.

Steel is widely used in the car body because of its inherent capability to absorb shock energy in a crash situation. In the past several decades, there were many developments that made the steel stronger, stiffer and lightweight. Particularly, low strength steels (interstitial free and mild steels), high strength steels (carbon-manganese, bake hardenable and high strength low alloy steels) and advanced high strength steels (dual-phase, complex phase, transformation induced plasticity and twinning induced plasticity) are very common for automotive ap-

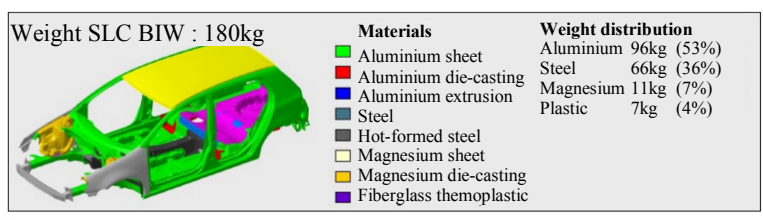

Fig. 1 Weight and material distribution in car body by SLC project $^{7)}$

plications ${ }^{11)}$. Presently, aluminum alloys are broadly used for car body production. The high strength and stiffness to weight ratio, formability and corrosion resistance make aluminum as a good candidate to replace heavier materials. The application of aluminum alloys is highly promising for car body parts such as roof, doors, and hood ${ }^{12)}$. Presently, the highly formable 5 XXX series alloys for inner panels and the heat-treatable $6 \mathrm{XXX}$ series alloys for outer panels are extensively used. Magnesium is another promising lightweight metal for automotive industries. Magnesium alloys are used for a variety of automotive applications including body, chassis, instrument panels, seat frames, steering structures, air-bag housings, and transmission system casings ${ }^{13-15)}$. Though magnesium is the lightest engineering metals being 35\% lighter than aluminum, its application is limited due to higher cost, low strength, low heat resistance, and poor wear and corrosion resistance ${ }^{16)}$. Table 1 presents the various properties of pure iron, aluminum, and magnesium ${ }^{17)}$. The incompatibility in their various properties makes it very difficult to produce sound welds. Polymer-based composites such as carbon fiber reinforced polymers (CFRP) and glass fiber reinforced polymer (GFRP) have the potential to reduce the weight of automotive structures because of their low density, and high strength and stiffness ${ }^{18)}$. But the higher manufacturing cost and complexity in joining restrict their wide applications.

\section{Dissimilar Materials Welding Processes}

A variety of welding processes for steel-Al alloy, Al alloy-Mg alloy and steel-Mg alloy dissimilar combinations can be broadly classified as fusion welding and solid-state welding. In the fusion welding, faying surfaces of base metals along with filler metal or without fill-

Table 1 Properties of $\mathrm{Fe}, \mathrm{Al}$ and $\mathrm{Mg}$

\begin{tabular}{|c|c|c|c|c|c|c|c|}
\hline Properties & $\begin{array}{c}\text { Melting } \\
\text { point }\left({ }^{\circ} \mathrm{C}\right)\end{array}$ & $\begin{array}{c}\text { Boiling } \\
\text { point }\left({ }^{\circ} \mathrm{C}\right)\end{array}$ & $\begin{array}{c}\text { Specific } \\
\text { heat } \\
(\mathrm{J} / \mathrm{kg} . \mathrm{K})\end{array}$ & $\begin{array}{c}\text { Heat } \\
\text { capacity } \\
\left(\mathrm{J} / \mathrm{m}^{3} \cdot \mathrm{K}\right)\end{array}$ & $\begin{array}{c}\text { Thermal } \\
\text { expansion rate } \\
\left(10^{-6} / \mathrm{K}\right)\end{array}$ & $\begin{array}{c}\text { Thermal } \\
\text { conductivity } \\
(\mathrm{W} / \mathrm{m} . \mathrm{K})\end{array}$ & $\begin{array}{c}\text { Density at } \\
\text { melting } \\
\left(\mathrm{kg} / \mathrm{m}^{3}\right)\end{array}$ \\
\hline $\mathrm{Fe}$ & 1538 & 2735 & 444 & 3494 & 12.2 & 73.3 & 238 \\
\hline $\mathrm{Al}$ & 660 & 2056 & 900 & 2430 & 23.9 & 2385 \\
\hline $\mathrm{Mg}$ & 650 & 1107 & 1022 & 1778 & 26.1 & 167 & 1590 \\
\hline
\end{tabular}




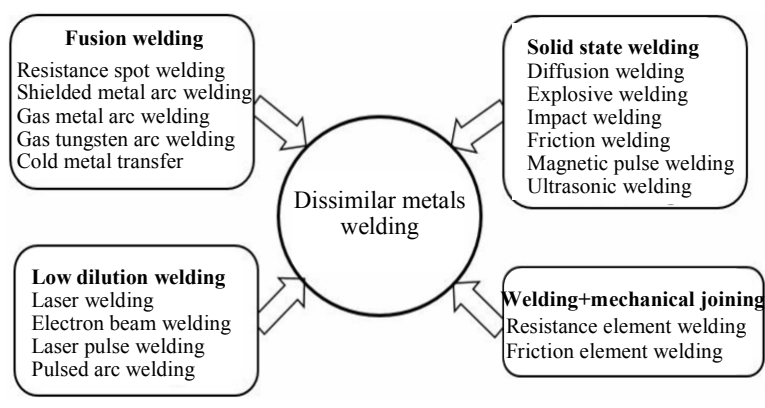

Fig. 2 Various processes for dissimilar metals welding

er metal are melted to form the weld. On the other hand, when base metals are heated to an elevated temperature less than the melting point and pressure is applied to form the weld, it is termed as solid-state welding. Low dilution welding is also one kind of fusion welding. It can be classified as the relatively less melting of base metals during welding ${ }^{19}$. The widely studied dissimilar metal welding processes are resistance spot welding ${ }^{20)}$, friction welding ${ }^{21)}$, friction stir welding ${ }^{22)}$, friction stir spot welding $^{23,24)}$, laser brazing ${ }^{25}$, diffusion welding ${ }^{26}$, explosive welding $^{27-29)}$, impact welding ${ }^{30}$, ultrasonic welding ${ }^{31-33)}$ and magnetic pressure seam welding ${ }^{34}$. Fig. 2. shows the various welding processes for dissimilar metals.

The fusion welding, solid-state welding, and mechanical joining processes are being extensively investigated for dissimilar metal joining. But, there are some key factors including the present infrastructures of automotive industries, joint performance, speed of the joining process, and manufacturing cost need to be considered for the selection of the joining process. The requirements of costly investment for complex equipment and the new layout of the plant, and longer processing time can intervene in the wide application of the solid-state welding and mechanical joining processes. In the present infrastructures of the industries, the application of fusion welding processes can be most convenient and economic. Resistance spot welding (RSW) is the most used welding process in automotive sectors ${ }^{35,36)}$. RSW is cheap and high-speed joining process that also provides dimensional accuracy ${ }^{10)}$. Electric arc welding is also very popular. Shielded metal arc welding (SMAW), gas metal arc welding (GMAW) and gas tungsten arc welding (GTAW) are the three common types of electric arc welding processes. Formation of the large heataffected zone (HAZ) and brittle IMCs are the main challenges of electric arc welding ${ }^{37}$. Friction welding is one broadly investigated solid-state welding process in multi-material structures. Friction welding can reduce thermal and metallurgical mismatch and brittle IMC phases. But the longer processing time of friction welding makes it costly and difficult to adapt in the manu- facturing process. Research on laser welding has been grown gradually in the past years. Laser welding sets low heat input by localized fusion that reduces HAZ and IMC layer thickness ${ }^{38)}$. But, laser welding also needs huge investment for a change or modification of the present infrastructures. Recently, hybrid welding has also drawn great attention from researchers and manufacturers. Hybrid welding is a joining method that combines two different welding processes simultaneously to form the same weld pool $^{39)}$. Furthermore, the hybridization of welding and mechanical joining is being investigated. Resistance element welding and friction element welding are the combinations of fusion welding and mechanical joining technologies which produce a fusion bond between an auxiliary element and the bottom sheet, and a mechanical locking between the element and the top sheet. From industrial point of view, the further development of resistance spot welding and electric arc welding for dissimilar metal joining can be the most convenient to avoid extra investment and higher manufacturing cost.

Achieving a good weld quality of dissimilar metal welding is not easy due to the formation of cracks and corrosion sensitive intermetallics. Various approaches were attempted by the many researchers to achieve good weld quality. The notable approaches are the application of interlayer, cover plate, low heat input, combination of welding and mechanical joining, and appropriate alloying of filler metals. Table 2 presents some of the attempts taken by different researchers to enhance the performance of dissimilar metal welds of steel-aluminum $^{40-62)}$, aluminum-magnesium ${ }^{63-69)}$, and steel-magnesium ${ }^{70-79)}$. In terms of present infrastructures in automotive industries, manufacturing cost, and weld quality the application of the least amount of heat input and appropriate filler metal alloys were identified as the most significant approaches. Though the application of cover plate, and interlayer or transition material can reduce the IMC layer thickness, but the addition of extra weight and cost can limit their applications. The resistance element welding facilitates welding between the element and the bottom sheet of similar materials, and can be a promising joining process in future automotive industries with the least modification of present infrastructures.

\section{Steel-Aluminum Welding}

Steels and aluminum alloys are the extensively used metals for automotive body manufacturing. Because of the unique combination of high strength and toughness of steels, and lightweight and formability of aluminum alloys, they are the most investigated dissimilar combi- 
Table 2 Various research approaches to enhance the performance of dissimilar metal welds

\begin{tabular}{|c|c|c|c|c|c|c|c|c|c|}
\hline Welding & \multicolumn{4}{|l|}{\begin{tabular}{|l|} 
Steel - \\
Aluminum
\end{tabular}} & \multicolumn{2}{|c|}{$\begin{array}{l}\text { Aluminum - } \\
\text { Magnesium }\end{array}$} & \multicolumn{2}{|c|}{$\begin{array}{l}\text { Steel - } \\
\text { Magnesium }\end{array}$} & Approaches \\
\hline $\begin{array}{l}\text { Metal inert gas (MIG) } \\
\text { welding }\end{array}$ & \multicolumn{3}{|c|}{ Nguyen et al. ${ }^{40)}$} & Shah et al. $^{41)}$ & \multicolumn{2}{|c|}{ Zhang et al. ${ }^{63)}$} & $\begin{array}{l}\text { Wang et } \\
\text { al. }\end{array}$ & $\begin{array}{l}\text { Liu et } \\
\text { al. }^{71)}\end{array}$ & Minimizing \\
\hline $\begin{array}{l}\text { Tungsten inert gas } \\
\text { (TIG) welding }\end{array}$ & \multicolumn{3}{|c|}{$\begin{array}{l}\text { Borrisutthekul et } \\
\text { al. }^{42)}\end{array}$} & Song et al. $^{43)}$ & \multicolumn{2}{|c|}{ Liu et al. ${ }^{64)}$} & \multicolumn{2}{|c|}{ Wang et al. ${ }^{72)}$} & heat input \\
\hline \multirow[t]{2}{*}{$\begin{array}{l}\text { Resistance spot } \\
\text { welding (RSW) }\end{array}$} & \multirow[t]{2}{*}{$\begin{array}{l}\text { Pouranvari } \\
\text { et al. }\end{array}$} & \multirow{2}{*}{\multicolumn{2}{|c|}{$\begin{array}{l}\text { Qui et } \\
\text { al. }^{45)} \\
\text { Satonaka } \\
\text { et al. }{ }^{46)}\end{array}$}} & \multirow{2}{*}{$\begin{array}{l}\text { Winnicki et al. }{ }^{47)} \\
\text { Baskoro et al. } \\
\text { Su et al. }{ }^{49)} \\
\text { Ibrahim et al. }{ }^{50)} \\
\text { Oikawa et al. } \\
\text { Sun et al. }\end{array}$} & \multirow{2}{*}{\multicolumn{2}{|c|}{$\begin{array}{l}\text { Zhang et al. } \\
\text { Sun et al. }\end{array}$}} & \multirow[t]{2}{*}{$\begin{array}{l}\text { Min et } \\
\text { al. }^{73)}\end{array}$} & \multirow[t]{2}{*}{$\begin{array}{l}\text { Feng et } \\
\text { al. }^{74}\end{array}$} & $\begin{array}{c}\text { Filler metal } \\
\text { Applying } \\
\text { cover plate }\end{array}$ \\
\hline & & & & & & & & & $\begin{array}{l}\text { Applying } \\
\text { interlayer }\end{array}$ \\
\hline Laser welding & \multicolumn{3}{|c|}{ Torkamany et al. $^{53)}$} & \multirow[t]{2}{*}{ Dharmendra et al. ${ }^{54}$} & $\begin{array}{l}\text { Chang et } \\
\text { al. }^{67)}\end{array}$ & $\begin{array}{l}\text { Liu et } \\
\text { al. } 64)\end{array}$ & \multicolumn{2}{|c|}{ Li et al. ${ }^{75)}$} & $\begin{array}{c}\text { Resistance } \\
\text { element } \\
\text { welding }\end{array}$ \\
\hline $\begin{array}{l}\text { Cold metal transfer } \\
\text { (CMT) }\end{array}$ & \multicolumn{3}{|c|}{$\begin{array}{l}\text { Jácome et al. }{ }^{55)} \\
\text { Kang et al. }\end{array}$} & & \multicolumn{2}{|c|}{ Shang et al. ${ }^{68)}$} & \multicolumn{2}{|c|}{ Ren et al. ${ }^{76)}$} & Friction \\
\hline $\begin{array}{l}\text { Friction stir welding } \\
\text { (FSW) }\end{array}$ & \multicolumn{4}{|c|}{ Watanabe et al. ${ }^{57)}$} & $\begin{array}{l}\text { Morishige } \\
\text { et al. }\end{array}$ & $\begin{array}{l}\text { Chang et } \\
\text { al. }{ }^{67)}\end{array}$ & \multicolumn{2}{|c|}{ Czerwinski et al. ${ }^{77)}$} & welding \\
\hline Element welding & \multicolumn{2}{|c|}{$\begin{array}{l}\text { Meschut et } \text { al. }^{58)} \\
\text { Qui et al. }{ }^{59)} \\
\text { Ling et al. }{ }^{60)} \\
\text { Ling et al. }\end{array}$} & \multicolumn{2}{|c|}{$\begin{array}{l}\text { Meschut et al. } \\
\text { Absar et al. }\end{array}$} & & & \multicolumn{2}{|c|}{$\begin{array}{l}\text { Manladan et al. }{ }^{78)} \\
\text { Manladan et al. }\end{array}$} & $\begin{array}{c}\text { Not } \\
\text { investigated }\end{array}$ \\
\hline
\end{tabular}

nations $^{38)}$. But the welding between steel and aluminum offers several metallurgical challenges due to their inherent incompatibility in mechanical, thermal and electrical properties ${ }^{80,81)}$. There are large differences in their melting temperatures, thermal and electrical conductivities, expansion coefficients, heat capacities, specific heats, and lattice transformation. Consequently, the weld quality is extremely influenced by this properties ${ }^{82)}$. Aluminum has nearly six times the thermal conductivity, three times the modulus of elasticity, twice the specific heat and thermal expansion than those of steel. Steel-aluminum alloy forms a weld-brazing joint as the welding temperature is more than the melting point of aluminum $\left(660^{\circ} \mathrm{C}\right.$, welding joint), but less than the melting point of steel $\left(1538^{\circ} \mathrm{C} \text {, brazing joint }\right)^{38)}$. Furthermore, the nearly zero solid solubility of $\mathrm{Fe}$ in $\mathrm{Al}$ forms a range of martensitic IMCs including $\mathrm{FeAl}_{3}$ and $\mathrm{Fe}_{2} \mathrm{Al}_{5}$ which are highly susceptible to low-strength, brittleness, cracks, and corrosion ${ }^{11,52,83-85)}$. As the steel-aluminum welding does not create homogenous microstructures, at least three different microstructural zones can be distinguished: a) fusion zone (FZ) or nugget formed by melting and re-solidifying of the metals, b) heat-affected zone (HAZ) which does not melt but changes microstructure and c) base metal (BM) does not show any significant metallurgical changes. Mismatching of strength amongst these three zones results in strain concentration at the weakest microstructure. In the atomic scale, the atoms of steel and aluminum can be interchanged during the welding process as diffusion of micro-solutes, movement of the grain boundaries and number of vacancies. The formation of intermetallic compounds basically de-

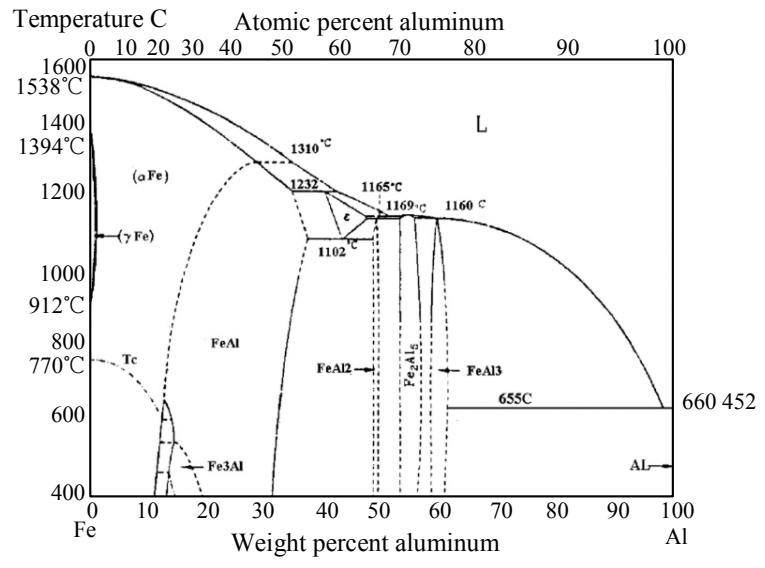

Fig. 3 Fe-Al phase diagram ${ }^{87}$

pends on three thermodynamic factors including the chemical potential of the elements, mobility of the elements and nucleation of the phases at the starting of diffusion $^{82,86)}$.

A wide range of IMCs is possible to be formed in the $\mathrm{Fe}-\mathrm{Al}$ system. The Fe-Al phase diagram (Fig. 3) is characterized by an iron-based solid solution and five intermetallic compounds of $\mathrm{FeAl}, \mathrm{FeAl}_{2}, \mathrm{FeAl}_{3}, \mathrm{Fe}_{2} \mathrm{Al}_{5}$, and $\mathrm{Fe}_{3} \mathrm{Al}$. In several studies, the higher amount of $\mathrm{Fe}_{2} \mathrm{Al}_{5}$ and less amount of $\mathrm{FeAl}_{3}$ phases were most importantly reported for fusion and solid-state welding ${ }^{88)}$, even for the application of $\mathrm{Al} / \mathrm{Fe}$ clad materials ${ }^{89)}$. Furthermore, the minor amount of $\mathrm{FeAl}_{2}$ was also found in some studies ${ }^{45)}$. The formation of $\mathrm{FeAl}$ and $\mathrm{Fe}_{3} \mathrm{Al}$ phases are difficult and not very common for their higher free energy ${ }^{90)}$. The formation and growth of $\mathrm{FeAl}_{3}$ and $\mathrm{Fe}_{2} \mathrm{Al}_{5}$ IMCs can be discussed in several steps with respect to time. Fig. 4 shows the schematic diagram of the four 

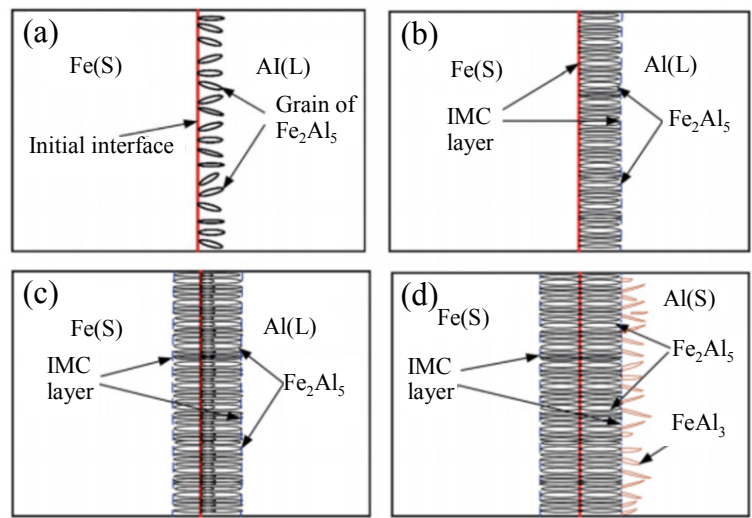

Fig. 4 Formation and growth of the IMC layer ${ }^{83)}$

stages for formation and growth sequences of $\mathrm{FeAl}_{3}$ and $\mathrm{Fe}_{2} \mathrm{Al}_{5}$ IMC layer. As soon as welding begins the temperature reaches the liquidus line of $\mathrm{Al}$ while the steel remains in solid-state. At first, $\mathrm{Al}$ atoms start to diffuse to the steel and plate-like $\mathrm{Fe}_{2} \mathrm{Al}_{5}$ IMCs start to nucleate in the interface between steel and Al. It forms an IMC layer sandwich between steel and $\mathrm{Al}$ which creates two new interfaces, one interface between $\mathrm{Fe}_{2} \mathrm{Al}_{5}$ IMC layer and steel, and another interface between $\mathrm{Fe}_{2} \mathrm{Al}_{5}$ IMC layer and Al. The growth of the $\mathrm{Fe}_{2} \mathrm{Al}_{5}$ IMCs is anisotropic, and preferably along the c-axis of the $\mathrm{Fe}_{2} \mathrm{Al}_{5}$ unit cell as $\mathrm{Fe}_{2} \mathrm{Al}_{5}$ crystalline lattice has $30 \%$ vacancies along the c-axis ${ }^{91)}$. Then, $\mathrm{Fe}$ and $\mathrm{Al}$ atoms migrate through the IMC layer associated with solid-state diffusion. The higher diffusivity of $\mathrm{Al}$ atoms in the $\mathrm{Fe}_{2} \mathrm{Al}_{5}$ IMC layer along this c-axis direction makes faster growth rates of $\mathrm{Fe}_{2} \mathrm{Al}_{5}$. The growth of the $\mathrm{Fe}_{2} \mathrm{Al}_{5}$ IMC layer functions as a barrier in the middle of solid steel and liquid Al. Gradually $\mathrm{Fe}_{2} \mathrm{Al}_{5}$ IMC layer becomes enough thicker that it almost entirely stops the coalescence between solid steel and liquid Al. As the Fe atoms are bigger than $\mathrm{Al}$ atoms, the diffusion of $\mathrm{Fe}$ atoms decreases through the $\mathrm{Fe}_{2} \mathrm{Al}_{5}$ IMC layer. It forms needle-like $\mathrm{FeAl}_{3}$ IMCs in the interface between $\mathrm{Al}$ and $\mathrm{Fe}_{2} \mathrm{Al}_{5}$ IMC layer. Fig. 5 shows the energy-dispersive X-ray spectroscopy (EDS) analysis of the steel-Al IMC layer. Here, the atomic ratio of $\mathrm{Al}$ and $\mathrm{Fe}$ explicates the presence of $\mathrm{FeAl}_{3}$ and $\mathrm{Fe}_{2} \mathrm{Al}_{5}$ in accordance with the for-
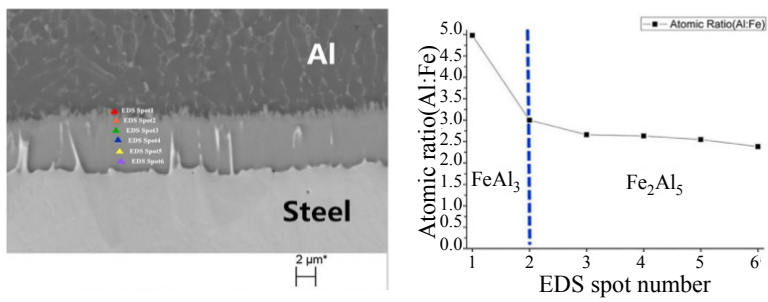

Fig. 5 Energy-dispersive X-ray spectroscopy of steel-Al IMC layer ${ }^{91)}$ mation mechanism of the IMC layer. The faster cooling of molten $\mathrm{Al}$ forms $\mathrm{FeAl}_{3}$ which interrupts the diffusion of $\mathrm{Al}$ atom to steel and changes the morphology and crystal orientation of $\mathrm{Fe}_{2} \mathrm{Al}_{5}$. When the temperature is below $450^{\circ} \mathrm{C}$, the diffusion coefficient of $\mathrm{D}_{\mathrm{Fe}-\mathrm{Al}}(\mathrm{Fe}$ in $\mathrm{Al})$ and $\mathrm{D}_{\mathrm{Al}-\mathrm{Fe}}(\mathrm{Al}$ in $\mathrm{Fe}$ ) are negligible, and when the temperature reaches at $450^{\circ} \mathrm{C}$, the diffusion coefficient of $\mathrm{D}_{\mathrm{Fe}-\mathrm{Al}}\left(8.95 * 10^{-11} \mathrm{~cm}^{2} / \mathrm{s}\right)$ is 106 times higher than $\mathrm{D}_{\mathrm{Al}-\mathrm{Fe}}\left(1.21 * 10^{-16} \mathrm{~cm}^{2} / \mathrm{s}\right)^{92)}$.

The intermetallic compounds significantly contribute to the mechanical properties of the welds. It is evident from most of the previous studies that the fractures mainly occurred through the IMC layers during the tensile test. The micro-cracks in the $\mathrm{Fe}_{2} \mathrm{Al}_{5}$ and $\mathrm{FeAl}_{3}$ layer dominated the location of the fractures. Internal micro-cracks may form in the IMC layers due to the mismatch of the thermal expansion coefficients between the materials ${ }^{89)}$. Furthermore, the hardness of the interfacial region increases because of the work hardening effect during the recrystallization of deformed plasticized zone ${ }^{93)}$. Table 3 presents the hardness values of $\mathrm{Fe}-\mathrm{Al}$ intermetallic phases at room temperature ${ }^{94)}$, and it was found that the hardness of Fe-Al intermetallics was much higher than that of base metals. Fig. 6 shows a schematic diagram of a typical hardness profile for steel-Al welding. The hardness decreases from the fusion zone (FZ) to base metal (BM). The FZ exhibits the maximum hardness, and in the heat-affected zone (HAZ), there is a gradual decrease in hardness from FZ to BM. In a previous

Table 3 Hardness of Fe-Al intermetallic phases ${ }^{94)}$

\begin{tabular}{|c|c|}
\hline Phases & Vickers Hardness $(9.8 \mathrm{~N})$ \\
\hline $\mathrm{Fe}(\mathrm{Steel})$ & $180-480$ \\
\hline $\mathrm{FeAl}$ & $491-667$ \\
\hline $\mathrm{FeAl}_{2}$ & $1058-1070$ \\
\hline $\mathrm{FeAl}_{3}$ & $772-1017$ \\
\hline $\mathrm{Fe}_{2} \mathrm{Al}_{5}$ & $1000-1158$ \\
\hline $\mathrm{Fe}_{3} \mathrm{Al}$ & $344-368$ \\
\hline $\mathrm{Al}(5 \mathrm{xxx}, 6 \mathrm{xxx})$ & $35-150$ \\
\hline
\end{tabular}

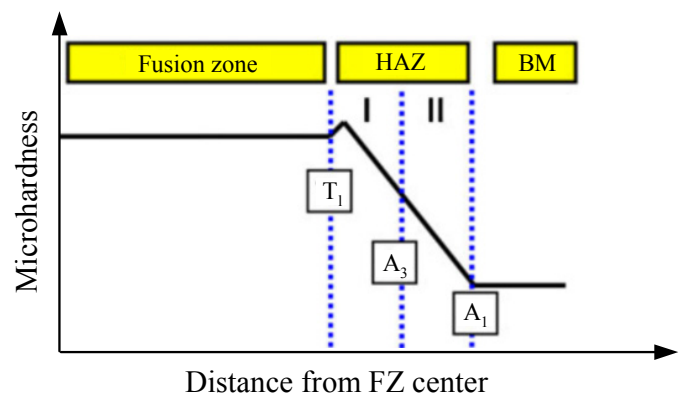

Fig. 6 Typical hardness profile schematic of steel-Al fusion weld ${ }^{11)}$ 
Table 4 Filler metal, IMCs, IMC layer thickness and fracture location of steel and aluminum welding

\begin{tabular}{|c|c|c|c|c|c|c|}
\hline $\begin{array}{l}\text { Welding } \\
\text { process }\end{array}$ & $\begin{array}{l}\text { Materials (aluminum } \\
\text { alloy/steel) \& Thickness }\end{array}$ & Filler metal & $\begin{array}{l}\text { IMC layer } \\
\text { thickness }(\mu \mathrm{m})\end{array}$ & IMC & Fracture zone/type & Ref. \\
\hline \multirow[t]{3}{*}{$\begin{array}{l}\text { Metal Inert } \\
\text { Gas (MIG) } \\
\text { Welding }\end{array}$} & $\begin{array}{l}\text { Al 2B50 } 1.0 \mathrm{~mm} / \\
\text { 1Cr18Ni9Ti } 1.0 \mathrm{~mm} \\
\text { (aluminized with } 50 \mu \mathrm{m} \\
\text { coating) }\end{array}$ & 4043 Al-Si & $\begin{array}{l}10 \text { (with } \\
\text { micro-cracks) }\end{array}$ & $\begin{array}{l}\mathrm{Al}_{86} \mathrm{Fe}_{14} \\
\mathrm{Al}_{0.7} \mathrm{Fe}_{3} \mathrm{Si}_{0.3}\end{array}$ & $\begin{array}{l}\text { Between fusion } \\
\text { zone and steel } \\
\text { base metal }\end{array}$ & 95) \\
\hline & $\begin{array}{l}\text { Al } 10601.0 \mathrm{~mm} / \text { Hot-dip } \\
\text { galvanized steel } 1.0 \mathrm{~mm}\end{array}$ & Al-Si & $\begin{array}{l}10 \text { (sample A) } \\
40-50 \text { (sample B) }\end{array}$ & $\begin{array}{l}\mathrm{Fe}_{2} \mathrm{Al}_{5} \\
\mathrm{FeAl}_{2}, \mathrm{FeAl}_{3}\end{array}$ & HAZ of $\mathrm{Al}$ & 96) \\
\hline & $\begin{array}{lll}6 \mathrm{~K} 21 & \mathrm{Al} & 1.6 \mathrm{~mm} / \\
\mathrm{SPRC} 440 & 1.4 \mathrm{~mm}\end{array}$ & $\begin{array}{l}4043 \\
\text { Al-Si }\end{array}$ & 3.2 (maximum) & $\begin{array}{l}\mathrm{FeAl}_{3} \\
\mathrm{Fe}_{2} \mathrm{Al}_{5}\end{array}$ & $\mathrm{HAZ}$ of $\mathrm{Al}$ & 97) \\
\hline $\begin{array}{l}\text { Tungsten Inert } \\
\text { Gas (TIG) } \\
\text { Welding }\end{array}$ & $\begin{array}{l}\text { Al 5A06 } 3.0 \mathrm{~mm} / \\
\text { SUS321 austenite stainless } \\
3.0 \mathrm{~mm}\end{array}$ & 4047 Al-Si & $\begin{array}{l}20-35 \text { (top) } \\
12 \text { (corner) } \\
<5 \text { (middle) }\end{array}$ & $\begin{array}{l}\mathrm{Al}_{7.2} \mathrm{Fe}_{2} \mathrm{Si} \\
\mathrm{Fe}_{2} \mathrm{Al}_{5} \\
\mathrm{FeSi}_{2}\end{array}$ & $\begin{array}{l}\text { Welded } \\
\text { seam and steel } \\
\text { interface }\end{array}$ & 85) \\
\hline \multirow{2}{*}{$\begin{array}{l}\text { Resistance } \\
\text { Spot Welding } \\
\text { (RSW) }\end{array}$} & 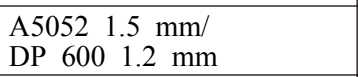 & - & $\begin{array}{l}3.3\left(\mathrm{Fe}_{2} \mathrm{Al}_{5}\right) \\
0.67-15.8\left(\mathrm{Fe}_{4} \mathrm{Al}_{13}\right)\end{array}$ & $\begin{array}{l}\mathrm{Fe}_{4} \mathrm{Al}_{13} \\
\mathrm{Fe}_{2} \mathrm{Al}_{5}\end{array}$ & $\begin{array}{l}\text { Elongated dimple } \\
\text { and cleavage }\end{array}$ & 98) \\
\hline & $\begin{array}{l}\text { EN AW 6008-T66 Al } 1.5 \mathrm{~mm} / \\
\text { Galvanized HSS } 1.0 \mathrm{~mm}\end{array}$ & - & $\begin{array}{l}5 \text { (lathlike) } \\
2.5-8 \text { (needle-like) }\end{array}$ & $\begin{array}{l}\mathrm{Fe}_{2} \mathrm{Al}_{5} \\
\mathrm{Fe}_{4} \mathrm{Al}_{13}\end{array}$ & Interfacial layer & 99) \\
\hline Laser Welding & $\begin{array}{l}\text { Al } 6016 \mathrm{~T} 41.2 \mathrm{~mm} / \mathrm{low} \\
\text { carbon DP600 steel } 0.77 \mathrm{~mm}\end{array}$ & $\mathrm{Zn}-15 \% \mathrm{Al}$ & $3-23$ & $\begin{array}{l}48 \% \mathrm{Al}, 31 \% \\
\mathrm{Fe} 21 \% \mathrm{Zn}\end{array}$ & $\begin{array}{l}\text { Welded seam and } \\
\text { steel interface }\end{array}$ & 100) \\
\hline \multirow[t]{2}{*}{$\begin{array}{l}\text { Cold Metal } \\
\text { Transfer } \\
(\mathrm{CMT})\end{array}$} & $\begin{array}{l}\text { Al } 6061-\mathrm{T} 62.0 \mathrm{~mm} / \mathrm{zinc} \\
\text { coated low-carbon steel } \\
1.2 \mathrm{~mm}\end{array}$ & ER 4043 & - & - & $\begin{array}{l}\text { HAZ close to } \\
\text { weld }\end{array}$ & 81) \\
\hline & $\begin{array}{l}\text { AA6061T6 } 1.0 \mathrm{~mm} / \\
\text { galvanized mild steel } \\
1.0 \mathrm{~mm}\end{array}$ & Al 4043 & - & $\begin{array}{l}\mathrm{Fe}_{3} \mathrm{Al}, \mathrm{FeAl}_{2} \\
\mathrm{FeAl}_{3}, \mathrm{Fe}_{2} \mathrm{Al}_{5}\end{array}$ & - & 101) \\
\hline $\begin{array}{l}\text { Friction Stir } \\
\text { Welding }\end{array}$ & $\begin{array}{l}\text { Al } 60161.2 \mathrm{~mm} / \\
\text { IF-steel } 2 \mathrm{~mm}\end{array}$ & - & 8 & $\begin{array}{l}\mathrm{FeAl}_{3} \\
\mathrm{Fe}_{2} \mathrm{Al}_{5} \\
\mathrm{FeAl}_{2} \\
\end{array}$ & - & 102) \\
\hline
\end{tabular}

study, it was found that the higher tensile strength can be obtained by reducing the amount of $\mathrm{IMCs}^{53)}$, and particularly Al-rich IMCs. The Al-rich intermetallics are more brittle in nature. When the amount of Al-rich IMCs increases, the IMC layer becomes thicker and the weld zone becomes more brittle ${ }^{52)}$. As a result, the strength of the weld reduces significantly. Therefore, the IMC layer thickness is one of the important factors to determine the bond strength of weld ${ }^{91)}$. A thinner IMC layer can improve the strength of the weld ${ }^{38)}$. Table 4 shows filler metal, intermetallic compounds, IMC layer thickness and fracture location of different steel and aluminum welding ${ }^{81,85,95-102)}$. The brittle intermetallics are formed in the weld zone. The weld zone becomes weaker than the base metals and leads to fracture through the interfacial layer of the fusion zone or the heat-affected zone. The IMC layer thickness varies for different material grades, sheet thickness, and surface coatings, alloying elements of filler metal, and welding processes. Moreover, IMC layer thickness also varies with different welding conditions. The IMC is thick at the center and gradually decreases in its thickness from the center to the periphery because of high temperature at the central region and low temperature at the peripheral region. Heat is one of the most important input parameters of welding, and the thickness of the IMC layer significantly increases with increasing heat input ${ }^{20,45)}$. Heat input increases with an increase of welding current. Therefore, the thickness of the IMC layer con- siderably depends on the welding current. Fig. 7 displays the relation between the welding current and IMC layer thickness. The IMC layer thickness gradually increases with the rising of welding current. The microstructure in HAZ of Al alloy becomes coarser when heat input increases. Thus, it can be said that the lower heat input obtains finer grain in HAZ of Al alloys. Fig. 8 presents the change of microstructure in $\mathrm{HAZ}$ of $\mathrm{Al}$ alloy when welding current rises from $100 \mathrm{~A}$ to $130 \mathrm{~A}$. It is found that the microstructure in HAZ of Al alloy is coarser for $130 \mathrm{~A}$ welding current. Heat input also increases with an increase in welding time or cycle. Therefore, the welding time can also influence IMC layer thickness. A
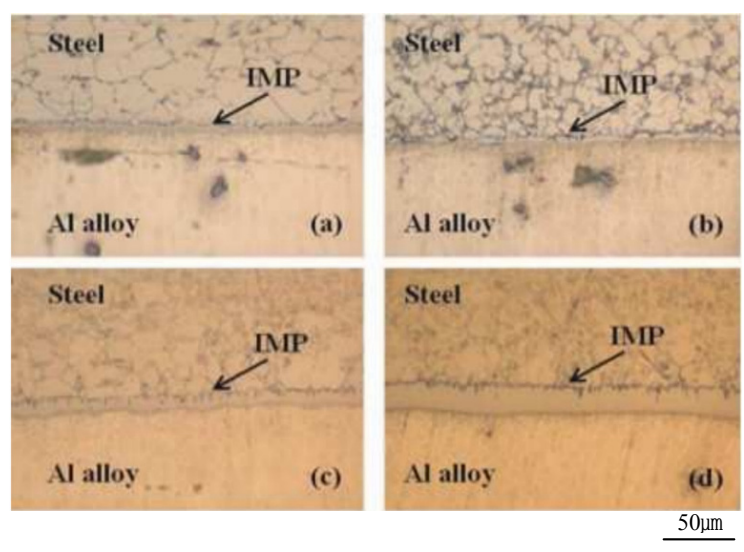

Fig. 7 IMC layer thickness at different welding current (a) $90 \mathrm{~A}$ (b) $110 \mathrm{~A} \mathrm{(c)} 130 \mathrm{~A}$ and (d) $150 \mathrm{~A}^{42)}$ 

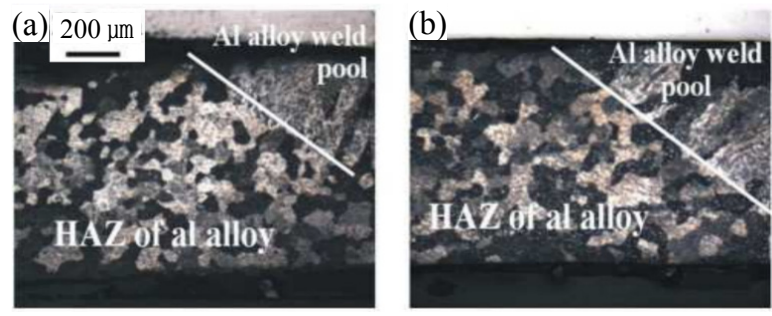

Fig. $8 \mathrm{HAZ}$ in $\mathrm{Al}$ alloy side at different welding current (a) $100 \mathrm{~A}$ and (b) $130 \mathrm{~A}^{42)}$

study reported the effect of different dwell time of welding on IMC layer thickness. IMC layer thickness increases with dwell time. Fig. 9 presents the growth of the IMC layer with an increase in dwell time. During lower heat input the IMC layer entirely consists of $\mathrm{Fe}_{2} \mathrm{Al}_{5}$. But when heat input increases, the IMC layer consists of $\mathrm{FeAl}_{2}$ and $\mathrm{FeAl}_{3} . \mathrm{FeAl}_{2}$ and $\mathrm{FeAl}_{3}$ are formed near the steel side and towards to weld zone, respectively ${ }^{96)}$. In another study, the microhardness of $\mathrm{FeAl}_{3}$ was found higher than that of $\mathrm{Fe}_{2} \mathrm{Al}_{5}$. Consequently, more cracks were formed in $\mathrm{FeAl}_{3}$ due to stresses generated during intermetallic reaction and cooling to room temperature ${ }^{87)}$. Another study also reported that the crack formation tendency was higher during higher heat input ${ }^{40)}$. Fig. 10 exhibits the formation of the cracks in the IMC layer during a higher amount of heat input. Therefore, controlling heat input is essential to reduce the number of intermetallic compounds, IMC layer thickness, and susceptibility of crack formation in the IMC layer.

The alloying elements of filler material is another important input parameter to determine the quality of the

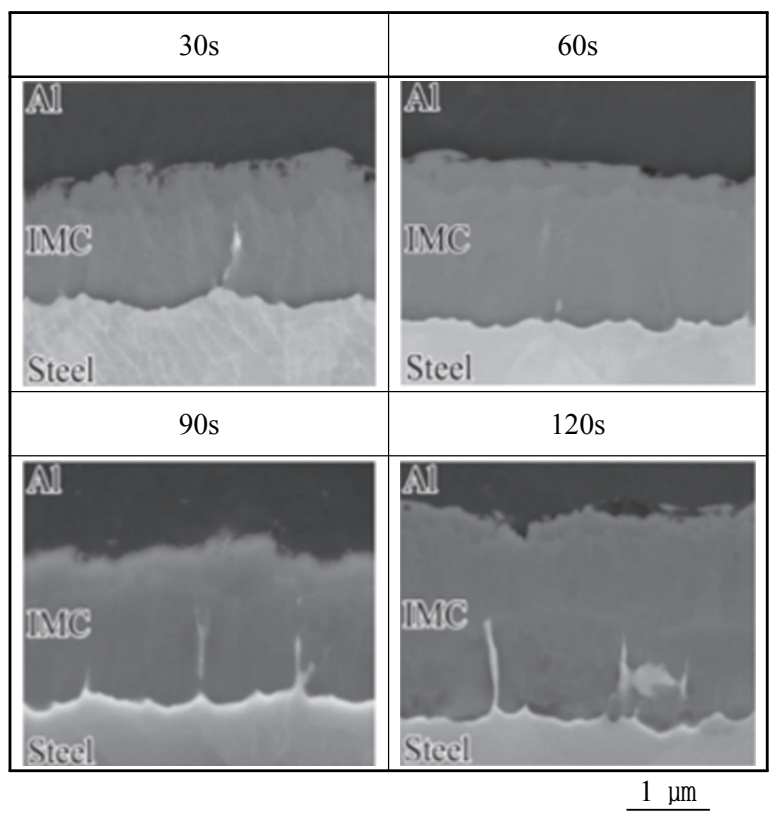

Fig. 9 Growth of IMC layer thickness in different dwell time $^{57)}$

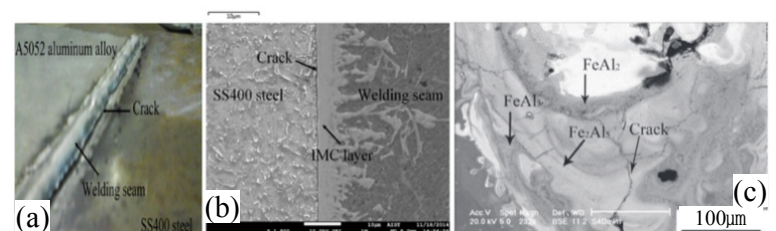

Fig. 10 Macro and micro cracks in thick IMC layer during a higher amount of heat input ${ }^{40,82)}$

dissimilar metal weld. In previous work, the weld strengths were evaluated using two different Al-12Si and $\mathrm{Al}-6 \mathrm{Cu}$ filler metals. Table 5 shows that the $\mathrm{Al}-6 \mathrm{Cu}$ filler metal can reduce the IMC layer thickness and subsequently improve the weld strength than that of Al$12 \mathrm{Si}$ filler metal ${ }^{43)}$. The IMC layers formed by Al-12Si filler metal shows high brittleness, while the IMC layer formed by $\mathrm{Al}-6 \mathrm{Cu}$ filler metal presents high crack resistance. The $\mathrm{Cu}$ atoms replaced $\mathrm{Fe}$ in IMC which may have reduced its hardness. Hence, the brittleness of IMC reduced and it resulted in the higher strength of weld with $\mathrm{Al}-6 \mathrm{Cu}$ filler metal. Therefore, the appropriate alloying elements in filler material effectively reduce the formation of brittle intermetallic compounds. In addition, the application of zinc coating as a sacrificial layer improves the weldability and fracture strength of steel-Al welds ${ }^{103)}$.

\section{Aluminum-Magnesium Welding}

Aluminum and Magnesium is two of the lightest structural metals. The application of aluminum alloys and magnesium alloys are increasing in automotive industries because of their high strength to weight ratio. From several studies, it is found that the formation of brittle IMCs is inevitable in Al-Mg welding under all conditions. Therefore, Al-Mg welding is also very challenging because of the formation of hard and brittle IMCs such as $\mathrm{Al}_{3} \mathrm{Mg}_{2}$ and $\mathrm{Al}_{12} \mathrm{Mg}_{17}$. The higher hardness value of these IMCs results in a low strength of the weld. Fig. 11 shows the binary phase diagram of $\mathrm{Al}-\mathrm{Mg}$ which consists of $\mathrm{Al}_{3} \mathrm{Mg}_{2}$ and $\mathrm{Al}_{12} \mathrm{Mg}_{17}$ IMCs and microhardness distribution of Al-Mg weld. The hardness is higher in the weld zone, and particularly, maximum at close to welding zone and magnesium interface.

In a study, the friction stir welding between $\mathrm{Al}$ alloy 1050 and $\mathrm{Mg}$ alloy AZ31 formed the IMC layer of $\mathrm{Al}_{12} \mathrm{Mg}_{17}$, and the hardness value of the IMC layer was measured between $150 \mathrm{HV}$ and $250 \mathrm{HV}^{104)}$. The hardness of $\mathrm{Al}_{12} \mathrm{Mg}_{17}$ was mentioned higher than those of base metals $\mathrm{Al}(27 \mathrm{HV})$ and $\mathrm{Mg}(55 \mathrm{HV})$. In another study, the brittleness of both $\mathrm{Al}_{3} \mathrm{Mg}_{2}$ and $\mathrm{Al}_{12} \mathrm{Mg}_{17}$ intermetallic compounds was reported as the main reason for weld cracks for friction stir welding of Al 5083 and 
Table 5 IMC and mechanical property of steel-Al welds using Al-12Si and Al-6Cu filler metals ${ }^{43)}$

\begin{tabular}{|c|c|c|c|c|c|c|}
\hline $\begin{array}{c}\text { Materials } \\
\text { (aluminum alloy/ } \\
\text { steel) \& Thickness }\end{array}$ & $\begin{array}{l}\text { Filler } \\
\text { metal }\end{array}$ & $\begin{array}{l}\text { IMC layer } \\
\text { thickness } \\
(\mu \mathrm{m})\end{array}$ & IMC & Microhardness & $\begin{array}{l}\text { Fracture } \\
\text { zone/type }\end{array}$ & $\begin{array}{l}\text { Tensile } \\
\text { Strength } \\
(\mathrm{MPa})\end{array}$ \\
\hline \multirow{2}{*}{$\begin{array}{c}\text { Al 5A06 } 3.0 \mathrm{~mm} / \\
\text { SUS321 stainless } \\
\text { steel } 3.0 \mathrm{~mm}\end{array}$} & $\begin{array}{l}4047 \\
\mathrm{Al}-\mathrm{Si}\end{array}$ & $6-8$ & $\begin{array}{c}\tau 5-\mathrm{Al}_{8} \mathrm{Fe}_{2} \mathrm{Si} \\
\text { h- }(\mathrm{Al}, \mathrm{Si})_{13} \mathrm{Fe}_{4}\end{array}$ & $\begin{array}{l}1025 \mathrm{HV}\left[\tau 5-\mathrm{Al}_{8} \mathrm{Fe}_{2} \mathrm{Si} \text { layer }\right] \\
835 \mathrm{HV}\left[\mathrm{h}-(\mathrm{Al}, \mathrm{Si})_{13} \mathrm{Fe}_{4} \text { layer }\right]\end{array}$ & $\begin{array}{c}\text { In } \mathrm{h}-(\mathrm{Al}, \mathrm{Si})_{13} \\
\mathrm{Fe}_{4} \text { layer }\end{array}$ & $100-120$ \\
\hline & $\begin{array}{l}2319 \\
\mathrm{Al}-\mathrm{Cu}\end{array}$ & $2-4$ & $\mathrm{~h}-\mathrm{Al}_{13}(\mathrm{Fe}, \mathrm{Cu})_{4}$ & $645 \mathrm{HV}\left[\mathrm{h}-\mathrm{Al}_{13}(\mathrm{Fe}, \mathrm{Cu})_{4}\right.$ layer $]$ & $\begin{array}{l}\text { In } \mathrm{h}-\mathrm{Al}_{13} \\
(\mathrm{Fe}, \mathrm{Cu})_{4}\end{array}$ & $155-175$ \\
\hline
\end{tabular}
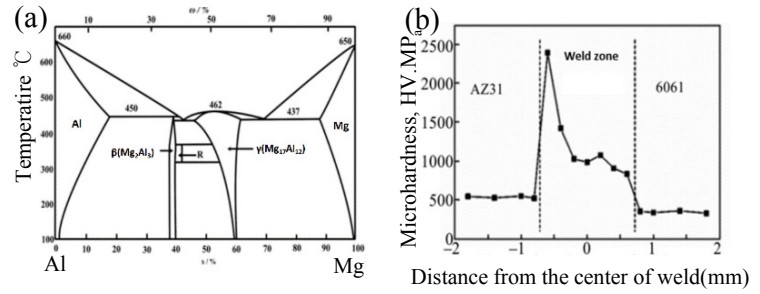

Fig. 11 (a) Al-Mg phase diagram ${ }^{17)}$, and (b) microhardness distribution of $\mathrm{Al}-\mathrm{Mg}$ weld ${ }^{68)}$

Mg AZ31. Fig. 12 shows the scanning electron microscopic (SEM) observation of Al-Mg interfaces with brittle intermetallic compounds ${ }^{105)}$. The weld joint of A5052H Al alloy and AZ31B Mg alloy by friction stir welding was investigated in a previous study. The formation of $\mathrm{Al}_{12} \mathrm{Mg}_{17}$ intermetallic compounds was evident which led to a brittle fracture in the stir zone (SZ). The hardness of the $\mathrm{Al}_{12} \mathrm{Mg}_{17}$ was measured 200-300 $\mathrm{HV}$ which was higher than those of base metals. The study also revealed that the formation of $\mathrm{Al}_{12} \mathrm{Mg}_{17}$ IMCs and the value of microhardness of the $\mathrm{Al}_{12} \mathrm{Mg}_{17}$ IMC can be decreased by reducing heat input ${ }^{69)}$.

Elements of filler metal can significantly influence the hardness value of the intermetallic compounds. A study investigated the welding between $\mathrm{Al} 6061$ and $\mathrm{Mg}$ AZ31B by cold metal transfer (CMT) process. Pure copper (HS201) was used as filler metal. A variety of Al-Cu IMCs ( $\mathrm{AlCu}, \mathrm{Al}_{2} \mathrm{Cu}$, and $\mathrm{Al}_{4} \mathrm{Cu}_{9}$ ) formed in the fusion zone of the $\mathrm{Al}$ side, while $\mathrm{Cu}_{2} \mathrm{Mg}$ and $\mathrm{Al}-\mathrm{Cu}-\mathrm{Mg}$ ternary eutectic structure formed in the fusion zone and

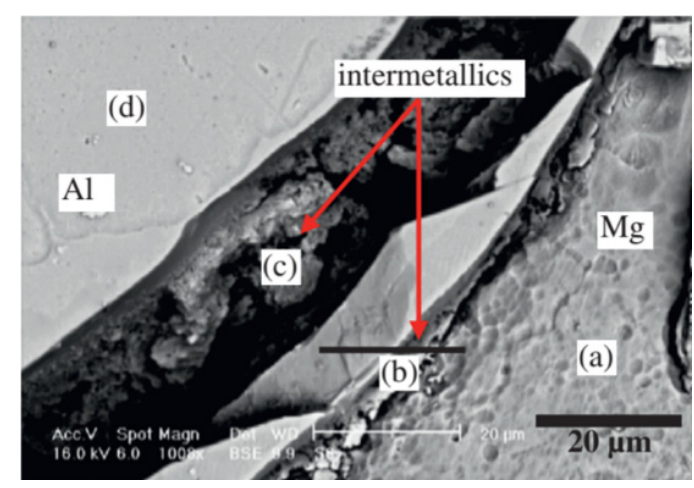

Fig. 12 SEM micrograph of Al-Mg welded specimen ${ }^{105)}$
$\mathrm{Mg}$ side. The microhardness value of the $\mathrm{Al}$ side and $\mathrm{Mg}$ side were measured as $260 \mathrm{HV}$ and $362 \mathrm{HV}$, respectively. The hardness value of IMCs was measured much higher than those of Al substrate (35-40 HV) and $\mathrm{Mg}$ substrate (50-55 HV). During the tensile strength test, fracture occurred in the fusion zone of the $\mathrm{Mg}$ side. The fracture mode was found as a brittle fracture. A large amount of $\mathrm{Cu}_{2} \mathrm{Mg}$ IMCs with maximum hardness value in the fusion zone was reported as the reason for the brittle fracture ${ }^{68)}$. In other work, an appreciable increase of tensile strength was found by the application of Ni foil filler metal for hybrid laser-friction stir welding between AA6061-T6 Al alloy and AZ31 Mg alloy. The presence of $\mathrm{NiAl}$ and $\mathrm{Ni}_{2} \mathrm{Mg}$ was reported as the reason for less amount of $\mathrm{Al}_{12} \mathrm{Mg}_{17}$ formation. The strength was enhanced because of the formation of less-brittle Nibased IMCs instead of the entire amount of $\mathrm{Al}_{12} \mathrm{Mg}_{17}$ brittle IMC ${ }^{67)}$.

\section{Steel-Magnesium Welding}

Welding of magnesium to steel is a challenging task because of the large differences in their melting points, thermal and electrical conductivities, and thermal expansion coefficients ${ }^{106)}$. The melting point of $\mathrm{Mg}$ and $\mathrm{Fe}$ are $650^{\circ} \mathrm{C}$ and $1538^{\circ} \mathrm{C}$, respectively. Moreover, a low boiling point $\left(1090^{\circ} \mathrm{C}\right)$ of $\mathrm{Mg}$ causes severe vaporization of $\mathrm{Mg}$ alloy when both the steel and $\mathrm{Mg}$ are heated to melt simultaneously. In these circumstances, the metallurgical bonding of $\mathrm{Mg}$ and steel is possible if an intermediate reaction layer is formed ${ }^{107)}$. Fig. 13 shows a phase diagram of Mg-Fe system. From the Mg-Fe binary phase diagram, it is evident that the less reactivity between these two metals makes it difficult to weld them directly. Moreover, the presence of oxide film on the $\mathrm{Mg}$ surface makes the welding more difficult ${ }^{108)}$. Therefore, two different approaches may be executed to weld $\mathrm{Mg}$ to steel. First, the alloying elements of $\mathrm{Mg}$ and steel can assist to form the intermetallic compounds in order to create the bond. Second, the addition of an interlayer between the base metals of $\mathrm{Mg}$ and steel can improve the mutual diffusion of alloying elements. But the same as the steel-Al and the Al-Mg welding, the 


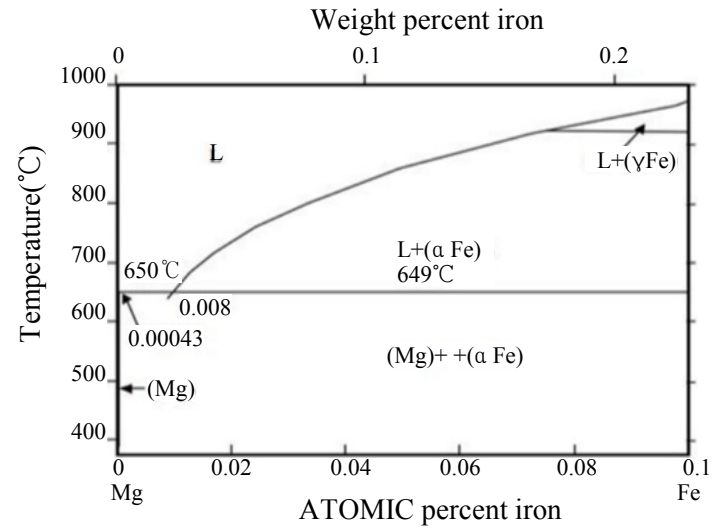

Fig. $13 \mathrm{Mg}-\mathrm{Fe}$ binary phase diagram ${ }^{108)}$

formation of brittle IMCs can be detrimental for the weld quality of steel-Mg.

The alloying elements, particularly $\mathrm{Al}$ in $\mathrm{Mg}$ alloy can significantly increase the weldability of $\mathrm{Mg}$ to steel. The Fe-Al system can form several intermetallic compounds. Consequently, the joint strength increases with the increase of $\mathrm{Al}$ content in the $\mathrm{Mg}$ alloy. It happens due to the depletion of $\mathrm{Al}$ at the $\mathrm{Mg}$ side of the IMC layer. The joint strength also increases with the decreasing of IMC layer thickness ${ }^{109)}$. Therefore, magnesium welding needs low and controlled heat input. The lower heat input can restrain the growth of the IMC layer.

The application of thin interlayers has been attempted to bond $\mathrm{Mg}$ to steel in some previous studies. HSLA steel and AZ31B-H24 Mg alloy were welded using an interlayer of Sn by ultrasonic spot welding ${ }^{110)}$. Fig. 14 (a) shows the weld without application of any interlayer where only some hydroxides are present. After the application of the Sn interlayer, the interlayer forms the $\mathrm{Sn}-\mathrm{Mg}_{2} \mathrm{Sn}$ eutectic structure. Fig. 14 (b) exhibits the eutectic $\mathrm{Sn}-\mathrm{Mg}_{2} \mathrm{Sn}$ layer between steel and $\mathrm{Mg}$ base metals. Fe was not observed in the IMC layer because of higher solubility of $\mathrm{Sn}$ in $\mathrm{Mg}$ than $\mathrm{Sn}$ in Fe. The lap shear strength of the Mg-steel joint with $\mathrm{Sn}$ interlayer was found higher than that of a similar joint without any interlayer.

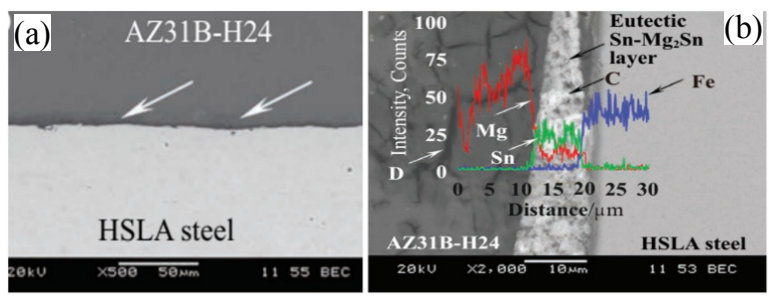

Fig. 14 Mg-steel weld (a) without Sn interlayer, and (b) with $\mathrm{Sn}$ interlayer ${ }^{110}$

\section{Corrosion of Dissimilar Metal Weld}

A dissimilar metal weld experiences physical, chemical and metallurgical changes. Accordingly, the corrosion properties of the weld and the heat-affected zone vary considerably. The thermal cycle of the welding process affects the microstructure and surface composition of welds and the adjacent base metals. The dissimilar metal welds of steel-Al, Al-Mg, and steel-Mg in car bodies often experience humid environments which may lead to corrosion damages. The dissimilar metal welds are vulnerable to galvanic corrosion, pitting corrosion, intergranular corrosion, hydrogen cracking and stress corrosion. In particular, the welds are highly prone to galvanic corrosion in several corrosive environments such as seawater, $\mathrm{CO}_{2}$ or moist air. The impact of galvanic corrosion is higher in a salt environment ${ }^{111)}$. Galvanic corrosion happens when two or more dissimilar materials are electrically connected in the same electrolyte ${ }^{112)}$. Several previous studies reported that the corrosion commenced from the weld zone because of its higher negative corrosion potential value over the base metals. There are several factors greatly affect the corrosion resistance of dissimilar metal welds. The number of intermetallic compounds and filler metals are the key factors of corrosion resistance for dissimilar metal weld.

A study investigated the corrosion properties of steelAl weld-brazing (pulsed double-electrode gas metal arc welding) lap joint with $\mathrm{Al}-5 \% \mathrm{Mg}$ filler metal ${ }^{112)}$. The IMCs formed at the interface of the weld led to the dissolution of the adjacent weld seam metals and accelerated the galvanic corrosion. The corrosion resistance of the weld decreased with an increase in IMC layer thickness. The heat input increased with the decrease of bypass current and resulted in a higher corrosion current density. Fig. 15 shows potentiodynamic polarization curves under various bypass current with the same total

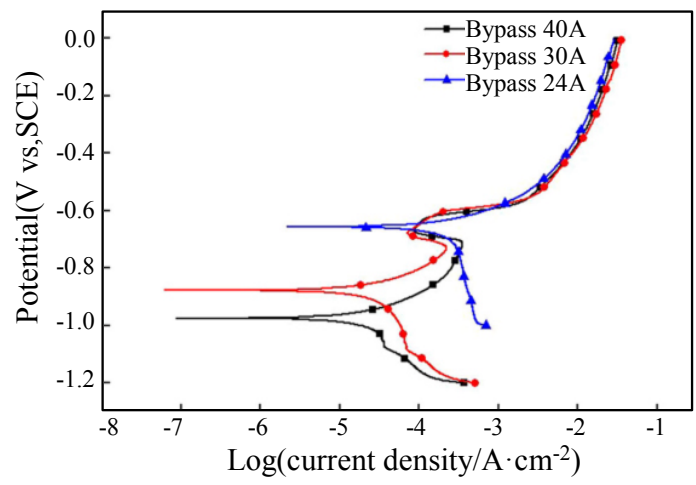

Fig. 15 Polarization curves of steel-Al weld under different bypass current ${ }^{112)}$ 

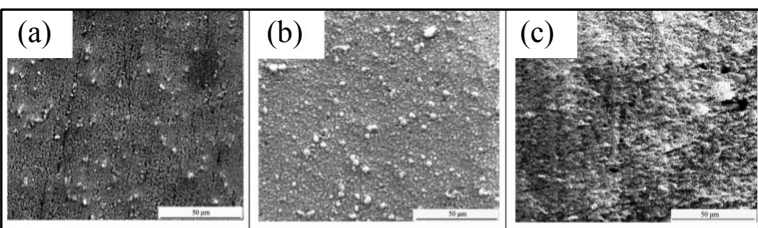

(d)

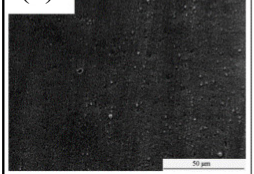

(e)
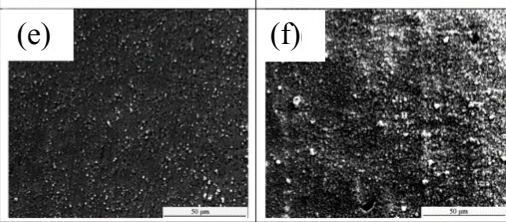

Fig. 16 Corrosion products of weld seam side at bypass current (a) $40 \mathrm{~A}$, (b) $30 \mathrm{~A}$, (c) $24 \mathrm{~A}$, and corrosion products of steel side at bypass current $(\mathrm{d})$ $40 \mathrm{~A}$, (e) $30 \mathrm{~A}$ and (f) $24 \mathrm{~A}^{112)}$

current of 64 A. Fig. 15 indicates an increase in current density with increasing heat input (or decreasing bypass current). Furthermore, the corrosion products of the steel side and the weld seam side increased with the increase of heat input. Fig. 16 presents the scanning electron microscopic images of the welds after 48 hours of immersion test at different bypass current of $40 \mathrm{~A}, 30 \mathrm{~A}$ and $24 \mathrm{~A}$, with same total current of $64 \mathrm{~A}$. The result disclosed that the amount of corrosion products reduced in both steel and weld seam side when the heat input was lower (or bypass current is higher).

Alloying elements of filler metals play an important role to determine the corrosion resistance of dissimilar metal welds. In a study, the corrosion resistance of hotdip galvanized steel-aluminum laser beam welds with $\mathrm{AlMg}_{6} \mathrm{Mn}$ and $\mathrm{ZnAl}_{2}$ filler metals were investigated ${ }^{113}$. Fig. 17 shows scanning electron microscopic images of before and after the 192 hours of salt spray test for $\mathrm{AlMg}_{6} \mathrm{Mn}$ and $\mathrm{ZnAl}_{2}$ filler metals. In both cases, the $\mathrm{Zn}-\mathrm{Al}$ has the most negative corrosion potential. Thus,

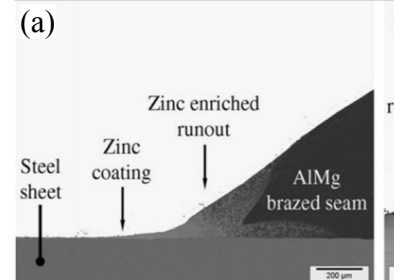

(c)

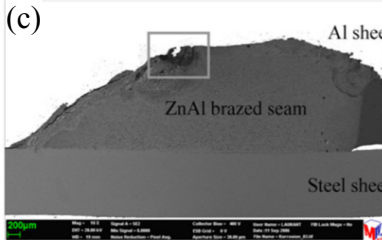

Fig. 17 (a) \& (b) before and after corrosion test of weld joint by AlMg6Mn filler metal, and (c) \& (d) before and after corrosion test of the weld joint by $\mathrm{ZnAl}_{2}$ filler metal $\left.{ }^{113}\right)$

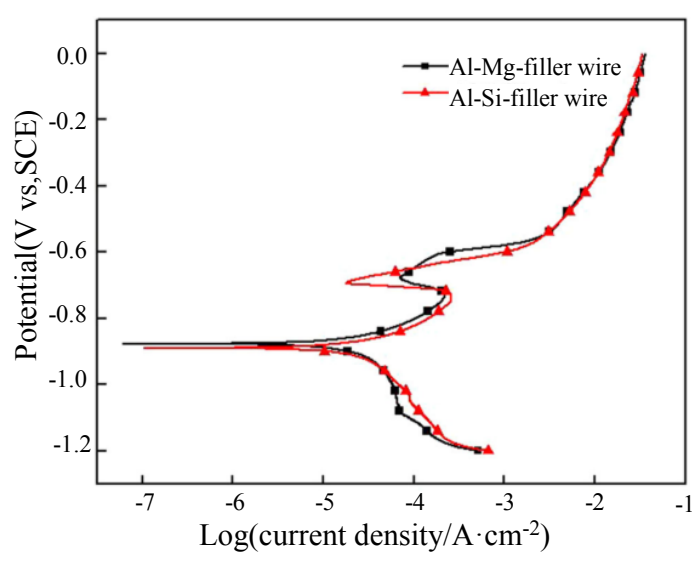

Fig. 18 Polarization curves of welds by different filler metals $^{112)}$

the forming $\mathrm{Zn}$-enriched runout corrodes first in the salt spray test of the weld joint with $\mathrm{AlMg}_{6} \mathrm{Mn}$ filler metal and the $\mathrm{Zn}-\mathrm{Al}$ microstructure forming in the runout of the brazed seam dissolve first in the salt spray test of the weld joint with $\mathrm{ZnAl}_{2}$ filler metal. The $\mathrm{ZnAl}_{2}$ filler metal weld displays higher corrosion resistance than that of $\mathrm{AlMg}_{6} \mathrm{Mn}$ filler metal weld. Another study evaluated the corrosion performance of steel-Al weld-brazing (gas metal arc welding) lap joints with $\mathrm{Al}-5 \% \mathrm{Mg}$ and $\mathrm{Al}-5 \% \mathrm{Si}$ filler metals ${ }^{112)}$. The polarization curves of welds are presented in Fig. 18. The corrosion current density of $\mathrm{Al}-5 \% \mathrm{Si}$ weld $\left(4.863 \times 10^{-5} \mathrm{~A} / \mathrm{cm}^{2}\right)$ is higher than that of $\mathrm{Al}-5 \% \mathrm{Mg}$ weld $\left(4.540 \times 10^{-5} \mathrm{~A} / \mathrm{cm}^{2}\right)$. As a result, compared to the $\mathrm{Al}-5 \% \mathrm{Si}$ filler metal, $\mathrm{Al}-5 \% \mathrm{Mg}$ filler metal enhanced the corrosion resistance of the steel-Al weld-brazing joints. Moreover, alloying and coating elements of metals also can remarkably change the corrosion resistance of welds. A study observed that the $\mathrm{Zn}-\mathrm{Al}-\mathrm{Mg}$ coatings on steel improved the corrosion resistance compared with conventional hot-dip and electro-galvanized coatings ${ }^{114)}$.

\section{Conclusion}

Recent developments of various lightweight materials have rejuvenated the automotive industry. But the joining of these dissimilar materials is still challenging for the manufacturers. The most promising steel-Al alloy, $\mathrm{Al}$ alloy-Mg alloy, and steel-Mg alloy dissimilar combinations and their metallurgical challenges to welding have been discussed throughout the paper. In the industrial point of view, the improvement of resistance spot welding and electric arc welding for multi-materials integration was realized as the most convenient and economical because of their established infrastructures. Minimizing intermetallic compounds were identified as 
a significant factor to enhance the weld quality of dissimilar metal welds. The control of heat input and the selection of alloying elements for filler metal can effectively reduce the amount of intermetallic compounds as well as the growth of IMC layer thickness. As a consequence, the brittle IMCs formation and the corrosion susceptibility of the weld zone can be considerably mitigated that can enhance the weld quality. The optimization of the welding process parameters for the least amount of heat input, selection of alloying elements for filler metals, base metals, and base metal coatings remain as leading issues for onward researches.

ORCID: Md. Abdul Karim: https://orcid.org/0000-0003-0954-3653 ORCID: Yeong-Do Park: https://orcid.org/0000-0002-0165-4749

\section{References}

1. M. Lee and S. Jung, Trends of Advanced Multi-Material Technology for Light Materials based on Aluminum, $J$. Weld. Join. 34(5) (2016) 19-25. https://doi.org/10.5781/JWJ.2016.34.5.19

2. M. Kang and C. Kim, A Review of Joining Processes for High Strength 7xxx Series Aluminum Alloys, J. Weld. Join. 35(6) (2017) 79-88. https://doi.org/10.5781/jwj.2017.35.6.12

3. A.H. Musfirah and A.G. Jaharah, Magnesium and Aluminum Alloys in Automotive Industry, J. Appl. Sci. Res. 8(9) (2012) 4865-4875.

4. W. S. Miller, L. Zhuang, J. Bottema, A.J. Wittebrood, P. De Smet, A. Haszler and A. Vieregge, Recent development in aluminium alloys for the automotive industry, Mater. Sci. Eng. A 280(1) (2000) 37-49.

https://doi.org/10.1016/S0921-5093(99)00653-X

5. A. Karim, J. Bae, D. Kam, C. Kim and Y. Park, Critical Influence of Rivet Head Height on Corrosion Performance of CFRP / Aluminum Self-Piercing Riveted Joints, Corros. Sci. Technol. 18(3) (2019) 92-101. https://doi.org/10.14773/cst.2019.18.3.92

6. M. Goede, M. Stehlin, L. Rafflenbeul, G. Kopp and E. Beeh, Super Light Car-lightweight construction thanks to a multi-material design and function integration, Eur. Transp. Res. Rev. 1(1) (2009) 5-10. https://doi.org/10.1007/s12544-008-0001-2

7. L. Berger, M. Lesemann, C. Sahr, S. Hart and R. Taylor, SuperLIGHT-CAR - the Multi-Material Car Body, 7th European LS-DYNA Conference, Salzburg, Austria (2009) 1-10.

8. S. A. Choudry, S. Müller, U. Alber, F. Riedel and D. Landgrebe, A Multidimensional Assessment and Selection Methodology, Optimized Decision-making of Joining Technologies in Automobile Body Development, Procedia Manuf. 21 (2018) 281-288.

https://doi.org/10.1016/j.promfg.2018.02.122

9. M. Marya, A Brief Review of Challenges \& Technologies to Weld Dissimilar Metals in Two Industries, The Upstream Oil \& Gas and the Automotive, Mater. Sci. Forum 580582 (2008) 155-158.

https://doi.org/10.4028/www.scientific.net/MSF.580-582.155

10. F. Shahid, A. A. Khan and M. Saqib Hameed, Mechanical and Microstuctural Analysis of Dissimilar Metal Welds, IJRRAS, 25(1) (2015) 6-14

11. M. Pouranvari and S. P. H. Marashi, Critical review of automotive steels spot welding, process, structure and properties, Sci. Technol. Weld. Join. 18(5) (2013) 361403. https://doi.org/10.1179/1362171813Y.0000000120

12. T. Sakayama, G. Murayma, Y. Naito, K. Saita, Y. Miyazakki, H. Oikawa and T. Nose, Dissimilar Metal Joining Technologies for Steel Sheet and Aluminum Alloy Sheet in Auto Body, Nippon Steel Tech. Rep. 393(103) (2013) 91-98.

13. M. J. F. Gándara, Recent Growing Demand for Magnesium in the Automotive Industry, Mater. Tehnol. 45(6) (2011) 633-637.

14. C. Blawert, N. Hort, and K. U. Kainer, Automotive Applications of Magnesium and Its Alloys, Trans. Indian Inst. Met. 57(4) (2004) 397-408. https://doi.org/10.4028/www.scientific.net/MSF.419-422.67

15. W. J. Joost and P. E. Krajewski, Towards Magnesium Alloys for High-volume Automotive Applications, Scr. Mater. 128 (2017) 107-112. https://doi.org/10.1016/j.scriptamat.2016.07.035

16. R. O. Hussein and D. O. Northwood, Improving the Performance of Magnesium Alloys for Automotive Applications, WIT Trans. Built Environ. 137 (2014) 531-544. https://doi.org/10.2495/HPSM140491

17. L. Liu, D. Ren, and F. Liu, A Review of Dissimilar Welding Techniques for Magnesium Alloys to Aluminum Alloys, Materials 7(5) (2014) 3735-3757. https://doi.org/10.3390/ma7053735

18. K. Friedrich and A. A. Almajid, Manufacturing Aspects of Advanced Polymer Composites for Automotive Applications, Appl. Compos. Mater. 20(2) (2013) 107128. https://doi.org/10.1007/s10443-012-9258-7

19. P. Kah and M. S. Jukka Martikainen, Trends in Joining Dissimilar Metals by Welding, Appl. Mech. Mater. 440 (2013) 269-276. https://doi.org/10.4028/www.scientific.net/AMM.440.269

20. R. Qiu, H. Shi, K. Zhang, Y. Tu, C. Iwamoto and S. Satonaka, Interfacial Characterization of Joint between Mild Steel and Aluminum Alloy Welded by Resistance Spot Welding, Mater. Charact. 61(7) (2010) 684-688. https://doi.org/10.1016/j.matchar.2010.03.015

21. A. Ambroziak, M. Korzeniowski and P. Kustroń, Friction Welding of Dissimilar Metal Joints with Intermediate Layers, J. Achievment Mater. Manuf. Eng. 21(2) (2007) 37-40. 
22. D. Campanella, P. R. Spena, G. Buffa and L. Fratini, Dissimilar Al/Steel Friction Stir Welding Lap Joints for Automotive Applications, AIP Conf. Proc., 1769 (2016) 100005. https://doi.org/10.1063/1.4963499

23. Y. F. Sun, H. Fujii, N. Takaki and Y. Okitsu, Microstructure and Mechanical Properties of Dissimilar Al Alloy/Steel Joints Prepared by a Flat Spot Friction Stir Welding Technique, Mater. Des. 47 (2013) 350-357. https://doi.org/10.1016/j.matdes.2012.12.007

24. H. Uzun, C. Dalle Donne, A. Argagnotto, T. Ghidini, and C. Gambaro, Friction Stir Welding of Dissimilar Al 6013-T4 To X5CrNi18-10 Stainless Steel, Mater. Des. 26(1) (2005) 41-46. https://doi.org/10.1016/j.matdes.2004.04.002

25. M. Lee, S.W. Kim, A. M. Nasiri and N. Y. Zhou, Effects of the Types of Coating on the Laser Brazing Characteristics of Dissimilar Joints between Mg Alloy and Steel Sheet, J. Korean Weld. Join. Soc. 31(4) (2013) 7-12. https://doi.org/10.5781/KWJS.2013.31.4.7

26. E. Akca and A. Gursel, The Effect of Diffusion Welding Parameters on the Mechanical Properties of Titanium Alloy and Aluminum Couples, Metals. 7(1) (2017) 22. https://doi.org/10.3390/met7010022

27. G. Costanza, V. Crupi, E. Guglielmino, A. Sili, and M. E. Tata, Metallurgical Characterization of an Explosion Welded Aluminum/Steel Joint Welding, La Metall. Ital. 11 (2016) 17-22

28. M. Acarer and B. Demir, An Investigation of Mechanical and Metallurgical Properties of Explosive Welded Aluminum-dual Phase Steel, Mater. Lett. 62(25) (2008) 4158-4160. https://doi.org/10.1016/j.matlet.2008.05.060

29. B. S. Zlobin, Explosion Welding of Steel with Aluminum, Combust. Explos. Shock Waves, 38(3) (2002) 374-377. https://doi.org/10.1023/A:1015674407898

30. H. Date, S. Kobayakawa and M. Naka, Microstructure and Bonding Strength of Impact-welded AluminiumStainless Steel Joints, J. Mater. Process. Technol. 85 (1999) 166-170. https://doi.org/10.1016/S0924-0136(98)00284-2

31. P. Prangnell, F. Haddadi and Y. C. Chen, Ultrasonic Spot Welding of Aluminium to Steel for Automotive Applications-Microstructure and Optimisation, Mater. Sci. Technol. 27(3) (2011) 617-624. https://doi.org/10.1179/026708310X520484

32. E. Kicukov and A. Gursel, Ultrasonic Welding of Dissimilar Materials: A Review, Period. Eng. Nat. Sci. 3(1) (2015). https://doi.org/10.21533/pen.v3i1.44

33. J. Tsujino, K. Hidai, A. Hasegawa, R. Kanai, H. Matsuura, K. Matsushima and T. Ueoka, Ultrasonic Butt Welding of Aluminum, Aluminum Alloy and Stainless Steel Plate Specimens, Ultrasonics 40 (1-8) (2002) 371-374. https://doi.org/10.1016/S0041-624x(02)00124-5
34. K. J. Lee, S. Kumai, T. Arai, and T. Aizawa, Interfacial Microstructure and Strength of Steel/Aluminum Alloy Lap Joint Fabricated by Magnetic Pressure Seam Welding, Mater. Sci. Eng. A. 471 (2007) 95-101. https://doi.org/10.1016/j.msea.2007.04.033

35. Devarasiddappa D, Automotive Applications of Welding Technology - A Study, Int. J. Mordern Eng. Res. 4(9) (2014) 13-19.

36. P. Penner, L. Liu, A. Gerlich, and Y. Zhou, Feasibility Study of Resistance Spot Welding of Dissimilar Al/Mg Combinations with Ni Based Interlayers, Sci. Technol. Weld. Join. 18(7) (2013) 541-550. https://doi.org/10.1179/1362171813Y.0000000129

37. K. Martinsen, S. J. Hu, and B. E. Carlson, Joining of Dissimilar Materials, CIRP Ann. - Manuf. Technol. 64(2) (2015) 679-699. https://doi.org/10.1016/j.cirp.2015.05.006

38. L. H. Shah and M. Ishak, Review of Research Progress on Aluminum-Steel Dissimilar Welding, Mater. Manuf. Process. 29(8) (2014) 928-933. https://doi.org/10.1080/10426914.2014.880461

39. G. Casalino, Advances in Welding Metal Alloys, Dissimilar Metals and Additively Manufactured Parts, Metals. 7(32) (2017). https://doi.org/10.3390/met7020032

40. Q. M. Nguyen and S. C. Huang, An Investigation of the Microstructure of an Intermetallic Layer in Welding Aluminum Alloys to Steel by MIG Process, Materials. 8(12) (2015) 8246-8254. https://doi.org/10.3390/ma8125444

41. L. H. Shah, Z. Akhtar and M. Ishak, Investigation of Aluminum-Stainless Steel Dissimilar Weld Quality Using Different Filler Metals, Int. J. Automot. Mech. Eng. 8(1) (2013) 1121-1131. https://doi.org/10.15282/ijame.8.2013.3.0091.

42. R. Borrisutthekul, P. Mitsomwang, S. Rattanachan and Y. Mutoh, Feasibility of Using TIG Welding in Dissimilar Metals between Steel / Aluminum Alloy, Energy Res. J. 1(2) (2010) 82-86. https://doi.org/10.3844/erjsp.2010.82.86

43. J. L. Song, S. B. Lin, C. L. Yang, C. L. Fan and G. C. $\mathrm{Ma}$, Analysis of Intermetallic Layer in Dissimilar TIG Welding-Brazing Butt Joint of Aluminium Alloy to Stainless Steel, Sci. Technol. Weld. Join. 15(3) (2010) 213-218. https://doi.org/10.1179/136217110X12665048207610

44. M. Pouranvari, Critical Assessment, Dissimilar Resistance Spot Welding of Aluminium/Steel, Challenges and Opportunities, Mater. Sci. Technol. 33(15) (2017) 17051712. https://doi.org/10.1080/02670836.2017.1334310

45. R. Qiu, C. Iwamoto and S. Satonaka, Interfacial Microstructure and Strength of Steel/Aluminum Alloy Joints Welded by Resistance Spot Welding with Cover Plate, J. Mater. Process. Technol. 209(8) (2009) 4186-4193. 
https://doi.org/10.1016/j.jmatprotec.2008.11.003

46. S. Satonaka, C. Iwamoto, R. Qui and T. Fujioka, Trends and New Applications of Spot Welding for Aluminium Alloy Sheets, Weld. Int. 20(11) (2006) 858-864. https://doi.org/10.1533/wint.2006.3677

47. M. Winnicki, A. Małachowska, M. Korzeniowski, M. Jasiorski and A. Baszczuk, Aluminium to steel resistance spot welding with cold sprayed interlayer, Surf. Eng. 34(3) (2017) 235-242.

https://doi.org/10.1080/02670844.2016.1271579

48. A. S. Baskoro, H. Muzakki, G. Kiswanto, and Winarto, Effect of Interlayer in Dissimilar Metal of Stainless Steel SS 301 and Aluminum Alloy AA 1100 Using Micro Resistance Spot Welding, AIP Conf. Proc. 1983(040014) (2018).

https://doi.org/10.1063/1.5046271

49. S. Su, S. Chen, Y. Mao, J. Xiao, A. Vivek and G. Daehn, Joining Aluminium Alloy 5A06 to Stainless Steel 321 by Vaporizing Foil Actuators Welding With an Interlayer, Metals. 9(43) (2019). https://doi.org/10.3390/met9010043

50. I. Ibrahim, R. Ito, T. Kakiuchi, Y. Uematsu, K. Yun and C. Matsuda, Fatigue Behaviour of Al/Steel Dissimilar Resistance Spot Welds Fabricated Using Al-Mg Interlayer, Sci. Technol. Weld. Join. 21(3) (2016) 223-233. https://doi.org/10.1179/1362171815Y.0000000086

51. H. Oikawa, S. Ohmiya, T. Yoshimura, and T. Saitoh, Resistance Spot Welding of Steel and Aluminium Sheet Using Insert Metal Sheet, Sci. Technol. Weld. Join. 4(2) (1999) 80-88. https://doi.org/10.1179/136217199101537608

52. X. Sun, E. V. Stephens, M. A. Khaleel, H. Shao and M. Kimchi, Resistance Spot Welding of Aluminum Alloy to Steel with Transition Material - From Process to Performance - Part I: Experimental Study, Weld. J. 83(6) (2004) 188-195.

53. M. J. Torkamany, S. Tahamtan and J. Sabbaghzadeh, Dissimilar Welding of Carbon Steel to 5754 Aluminum Alloy by Nd:YAG Pulsed Laser, Mater. Des. 31(1) (2010) 458-465. https://doi.org/10.1016/j.matdes.2009.05.046

54. C. Dharmendra, K. P. Rao, J. Wilden and S. Reich, Study on Laser Welding-Brazing of Zinc Coated Steel to Aluminum Alloy with a Zinc Based Filler, Mater. Sci. Eng. A. 528(3) (2011) 1497-1503. https://doi.org/10.1016/j.msea.2010.10.050

55. L. A. Jácome, S. Weber, A. Leitner, E. Arenholz, J. Bruckner, H. Hackl and A. R. Pyzalla, Influence of Filler Composition on the Microstructure and Mechanical Properties of Steel-Aluminum Joints Produced by Metal Arc Joining, Adv. Eng. Mater. 11(5) (2009) 350-358. https://doi.org/10.1002/adem.200800319

56. M. Kang and C. Kim, Joining Al 5052 Alloy to Aluminized Steel Sheet Using Cold Metal Transfer Process, Mater.
Des. 81 (2015) 95-103.

https://doi.org/10.1016/j.matdes.2015.05.035

57. M. Watanabe, K. Feng, Y. Nakamura and S. Kumai, Growth Manner of Intermetallic Compound Layer Produced at Welding Interface of Friction Stir Spot Welded Aluminum/Steel Lap Joint, Mater. Trans. 52(5) (2011) 953-959.

https://doi.org/10.2320/matertrans.L-MZ201120

58. G. Meschut, V. Janzen and T. Olfermann, Innovative and Highly Productive Joining Technologies for Multi-material Lightweight Car Body Structures, $J$. Mater. Eng. Perform. 23(5) (2014) 1515-1523. https://doi.org/10.1007/s11665-014-0962-3

59. R. Qiu, N. Wang, H. Shi, L. Cui, L. Hou and K. Zhang, Joining Steel to Aluminum Alloy by Resistance Spot Welding with a Rivet, Int. J. Mater. Res. 106(1) (2015) 60-65.

https://doi.org/10.3139/146.111146

60. Z. Ling, Y. Li, Z. Luo, Y. Feng and Z. Wang, Resistance Element Welding of 6061 Aluminum Alloy to Uncoated 22MnMoB Boron Steel, Mater. Manuf. Process. 31(16) (2016) 2174-2180. https://doi.org/10.1080/10426914.2016.1151044

61. Z. Ling, Y. Li, Z. Luo, S. Ao, Z. Yin, Y. Gu and Q. Chen, Microstructure and Fatigue Behavior of Resistance Element Welded Dissimilar Joints of DP780 Dualphase Steel to 6061-T6 Aluminum Alloy, Int. J. Adv. Manuf. Technol. 92(5-8) (2017) 1923-1931. https://doi.org/10.1007/s00170-017-0310-5

62. S. Absar, B. J. Ruszkiewicz, J. D. Skovron, L. Mears, T. Abke, X. Zhao and H. Choi, Temperature measurement in friction element welding process with micro thin film thermocouples, Procedia Manuf. 26 (2018) 485-494. https://doi.org/10.1016/j.promfg.2018.07.057

63. H. T. Zhang and J. Q. Song, Microstructural Evolution of Aluminum/Magnesium Lap Joints Welded Using MIG Process with Zinc Foil as an Interlayer, Mater. Lett. 65(21-22) (2011) 3292-3294. https://doi.org/10.1016/j.matlet.2011.05.080

64. L. Liu, X. Liu and S. Liu, Microstructure of Laser-TIG Hybrid Welds of Dissimilar Mg Alloy and Al Alloy with Ce as Interlayer, Scr. Mater. 55(4) (2006) 383-386. https://doi.org/10.1016/j.scriptamat.2006.04.025

65. Y. Zhang, Z. Luo, Y. Li, Z. M. Liu, and Z. Y. Huang, Microstructure Characterization and Tensile Properties of Mg/Al Dissimilar Joints Manufactured by Thermocompensated Resistance Spot Welding with Zn Interlayer, Mater. Des. 75 (2015) 166-173.

https://doi.org/10.1016/j.matdes.2015.03.030

66. M. Sun, S. T. Niknejad, H. Gao, L. Wu and Y. Zhou, Mechanical Properties of Dissimilar Resistance Spot Welds of Aluminum to Magnesium with Sn-coated Steel Interlayer, Mater. Des. 91 (2016) 331-339. https://doi.org/10.1016/j.matdes.2015.11.121 
67. W. S. Chang, S. R. Rajesh, C. K. Chun and H. J. Kim, Microstructure and Mechanical Properties of Hybrid Laser-Friction Stir Welding between AA6061-T6 Al Alloy and AZ31 Mg Alloy, J. Mater. Sci. Technol. 27(3) (2011) 199-204.

https://doi.org/10.1016/S1005-0302(11)60049-2

68. J. Shang, K. Wang, Q. Zhou, D. Zhang, J. Huang and G. Li, Microstructure Characteristics and Mechanical Properties of Cold Metal Transfer Welding Mg/Al Dissimilar Metals, Mater. Des. 34 (2012) 559-565. https://doi.org/10.1016/j.matdes.2011.05.008

69. T. Morishige, A. Kawaguchi, M. Tsujikawa, M. Hino, T. Hirata and K. Higashi, Dissimilar Welding of Al and Mg Alloys by FSW, Mater. Trans. 49(5) (2008) 11291131 . https://doi.org/10.2320/matertrans.MC200768

70. X. Y. Wang, X. Y. Gu, D. Q. Sun and C. Y. Xi, Interface characteristics and mechanical behavior of metal inert-gas arc welded $\mathrm{Mg}$-steel joints, J. Mater. Res. 31(5) (2016) 589-598. https://doi.org/10.1557/jmr.2016.43

71. S. Liu, D. Sun, X. Gu and H. Li, Microstructures and Mechanical Properties of Metal Inert-gas Arc Welded Joints of Mg Alloy and Ultra-high Strength Steel, J. Mater. Res. 32(4) (2017) 843-851. https://doi.org/10.1557/jmr.2016.515

72. H. Wang and G. Song, Influence of Adhesive and Ni on the Interface between $\mathrm{Mg}$ and $\mathrm{Fe}$ in the LaserTIG-adhesive Hybrid Welding Joint, Int. J. Precis. Eng. Manuf. 17(6) (2016) 823-827. https://doi.org/10.1007/s12541-016-0101-1

73. D. Min, Z. Yong and L. Jie, Dissimilar Spot Welding Joints of AZ31-443 Ferritic Stainless Steel with Cover Plate, Int. J. Adv. Manuf. Technol. 85(5-8) (2016) 15391545. https://doi.org/10.1007/s00170-015-8078-y

74. Y. Feng, Y. Li, Z. Luo, Z. Ling and Z. Wang, Resistance Spot Welding of Mg to Electro-galvanized Steel with Hot-dip Galvanized Steel Interlayer, J. Mater. Process. Technol. 236 (2016) 114-122. https://doi.org/10.1016/j.jmatprotec.2016.05.015

75. L. Li, C. Tan, Y. Chen, W. Guo and F. Song, Comparative Study on Microstructure and Mechanical Properties of Laser Welded-brazed Mg/Mild Steel and Mg/Stainless Steel Joints, Mater. Des. 43 (2013) 59-65. https://doi.org/10.1016/j.matdes.2012.06.057

76. D. Ren and L. Liu, Interface Microstructure and Mechanical Properties of Arc Spot Welding Mg-Steel Dissimilar Joint with Cu Interlayer, Mater. Des. 59 (2014) 369-376. https://doi.org/10.1016/j.matdes.2014.03.006

77. F. Czerwinski, Welding and Joining of Magnesium Alloys, InTech (2011). https://doi.org/10.5772/13947

78. S. M. Manladan, F. Yusof, S. Ramesh, Y. Zhang, Z. Luo and Z. Ling, Resistance Element Welding of Magnesium Alloy/austenitic Stainless Steel, IOP Conf. Ser. Mater. Sci. Eng., 238(012004) (2017). https://doi.org/10.1088/1757-899X/238/1/012004

79. S. M. Manladan, F. Yusof, S. Ramesh, Y. Zhang, Z. Luo and Z. Ling, Microstructure and Mechanical Properties of Resistance Spot Welded in Welding-Brazing Mode and Resistance Element Welded Magnesium Alloy/ Austenitic Stainless Steel Joints, J. Mater. Process. Technol. 250 (2017) 45-54. https://doi.org/10.1016/j.jmatprotec.2017.07.006

80. E. Taban, J. E. Gould and J. C. Lippold, Dissimilar Friction Welding of 6061-T6 Aluminum and AISI 1018 Steel, Properties and Microstructural Characterization, Mater. Des. 31(5) (2010) 2305-2311. https://doi.org/10.1016/j.matdes.2009.12.010

81. S. Yang, J. Zhang, J. Lian and Y. Lei, Welding of Aluminum Alloy to Zinc Coated Steel by Cold Metal Transfer, Mater. Des. 49 (2013) 602-612. https://doi.org/10.1016/j.matdes.2013.01.045

82. M. M. Atabaki, M. Nikodinovski, P. Chenier, J. Ma, M. Harooni and R. Kovacevic, Welding of Aluminum Alloys to Steels, An Overview, J. Manuf. Sci. Prod. 14(2) (2014) 59-78. https://doi.org/10.1515/jmsp-2014-0007

83. G. Zhang, M. Chen, Y. Shi, J. Huang, and F. Yang, Analysis and Modeling of the Growth of Intermetallic Compounds in Aluminum-Steel Joints, RSC Adv. 7(60) (2017) 37797 37805 . https://doi.org/10.1039/c7ra06354g

84. G. Liedl, R. Bielak, J. Ivanova, N. Enzinger, G. Figner, J. Bruckner, H. Pasic, M. Pudar and S. Hampel, Joining of Aluminum and Steel in Car Body Manufacturing, Phys. Procedia. 12 (2011) 150-156. https://doi.org/10.1016/j.phpro.2011.03.019

85. J. L. Song, S. B. Lin, C. L. Yang, G. C. Ma, and H. Liu, Spreading Behavior and Microstructure Characteristics of Dissimilar Metals TIG Welding-Brazing of Aluminum Alloy to Stainless Steel, Mater. Sci. Eng. A. 509(1-2) (2009) 31-40. https://doi.org/10.1016/j.msea.2009.02.036

86. H. Springer, A. Kostka, E. J. Payton, D. Raabe, A. KaysserPyzalla, and G. Eggeler, On the Formation and Growth of Intermetallic Phases During Interdiffusion between Low-carbon Steel and Aluminum Alloys, Acta Mater. 59(4) (2011) 1586-1600.

https://doi.org/10.1016/j.actamat.2010.11.023

87. H. R. Shahverdi, M. R. Ghomashchi, S. Shabestari, and J. Hejazi, Microstructural Analysis of Interfacial Reaction between Molten Aluminum and Solid Iron, J. Mater. Process. Technol. 124 (2002) 345-352. https://doi.org/10.1016/S0924-0136(02)00225-X

88. L. Xu, L. Wang, Y. C. Chen, J. D. Robson, and P. B. Prangnell, Effect of Interfacial Reaction on the Mechanical Per- 
formance of Steel to Aluminum Dissimilar Ultrasonic Spot Welds, Metall. Mater. Trans. A. 47(1) (2016) 334-346.

https://doi.org/10.1007/s11661-015-3179-7

89. Q. Wang, X. S. Leng, T. H. Yang, and J. C. Yan, Effects of $\mathrm{Fe}$ - Al Intermetallic Compounds on Interfacial Bonding of Clad Materials, Trans. Nonferrous Met. Soc. China. 24(1) (2014) 279-284. https://doi.org/10.1016/S1003-6326(14)63058-2

90. R. W. Richards, R. D. Jones, P. D. Clements, and H. Clarke, Metallurgy of Continuous Hot Dip Aluminising, Int. Mater. Rev. 39(5) (1994) 191-212.

https://doi.org/http://dx.doi.org/10.1179/imr.1994.39.5.191

91. Z. Wan, H. P. Wang, N. Chen, M. Wang, and B. E. Carlson, Characterization of Intermetallic Compound at the Interfaces of Al-Steel Resistance Spot Welds, $J$. Mater. Process. Technol. 242 (2017) 12-23. https://doi.org/10.1016/j.jmatprotec.2016.11.017

92. Y. G. Du, Y. A. Chang, B. Huang, W. Gong, Z. Jin, H. $\mathrm{Xu}, \mathrm{Z}$. Yuan, Y. Liu, Y. He and F. Y. Xie, Diffusion Coefficients of Some Solutes in FCC and Liquid Al: Critical Evaluation and Correlation, Mater. Sci. Eng. A. 363(1-2) (2003) 140-151. https://doi.org/10.1016/S0921-5093(03)00624-5

93. N. R. J. Hynes, P. Nagaraj, and J. A. J. Sujana, Investigation on Joining of Aluminum and Mild Steel by Friction stud Welding, Mater. Manuf. Process. 27(12) (2012) 1409-1413. https://doi.org/10.1080/10426914.2012.667894

94. M. Potesser, T. Schoeberl, H. Antrekowitsch, and J. Bruckner, The Characterization of the Intermetallic Fe-Al Layer of Steel-Aluminum Weldings, TMS Annual Meeting (2006) 167-176.

95. H. Zhang and J. Liu, Microstructure Characteristics and Mechanical Property of Aluminum Alloy/Stainless Steel Lap Joints Fabricated by MIG Welding-Brazing Process, Mater. Sci. Eng. A. 528 (19-20) (2011) 61796185. https://doi.org/10.1016/j.msea.2011.04.039

96. H. T. Zhang, J. C. Feng, P. He, and H. Hackl, Interfacial Microstructure and Mechanical Properties of Aluminiumzinc-coated Steel Joints Made by a Modified Metal Inert Gas Welding-Brazing Process, Mater. Charact. 58(7) (2007) 588-592. https://doi.org/10.1016/j.matchar.2006.07.008

97. H. J. Park, S. Rhee, M. J. Kang, and D. C. Kim, Joining of Steel to Aluminum Alloy by AC Pulse MIG Welding, Mater. Trans. 50(9) (2009) 2314-2317. https://doi.org/10.2320/matertrans.M2009105

98. J. Chen, X. Yuan, Z. Hu, C. Sun, Y. Zhang, and Y. Zhang, Microstructure and Mechanical Properties of Resistancespot-welded Joints for A5052 Aluminum Alloy and DP 600 Steel, Mater. Charact. 120 (2016) 45-52. https://doi.org/10.1016/j.matchar.2016.08.015
99. W. H. Zhang, X. M. Qiu, D. Q. Sun, and L. J. Han, Effects of Resistance Spot Welding Parameters on Microstructures and Mechanical Properties of Dissimilar Material Joints of Galvanised High Strength Steel and Aluminium Alloy, Sci. Technol. Weld. Join. 16(2) (2011) 153-161. https://doi.org/10.1179/1362171810Y.0000000009

100. C. Dharmendra, K. P. Rao, J. Wilden and S. Reich, Study on Laser Welding-Brazing of Zinc Coated Steel to Aluminum Alloy with a Zinc Based Filler, Mater. Sci. Eng. A. 528(3) (2011) 1497-1503. https://doi.org/10.1016/j.msea.2010.10.050

101. R. Cao, G. Yu, J. H. Chen and P. C. Wang, Cold Metal Transfer Joining Aluminum Alloys-to-Galvanized Mild Steel, J. Mater. Process. Technol. 213(10) (2013) 1753-1763. https://doi.org/10.1016/j.jmatprotec.2013.04.004

102. M. J. Rathod and M. Kutsuna, Joining of Aluminum Alloy 5052 and Low-Carbon Steel by Laser Roll Welding, Weld Res. 83(1) (2004) 16-26.

103. Y. C. Chen and K. Nakata, Effect of the Surface State of Steel on the Microstructure and Mechanical Properties of Dissimilar Metal Lap Joints of Aluminum and Steel by Friction Stir Welding, Metall. Mater. Trans. A. 39(8) (2008) 1985-1992. https://doi.org/10.1007/s11661-008-9523-4

104. Y. S. Sato, S. H. C. Park, M. Michiuchi and H. Kokawa, Constitutional Liquation during Dissimilar Friction Stir Welding of Al and Mg Alloys, Scr. Mater. 50(9) (2004) 1233-1236. https://doi.org/10.1016/j.scriptamat.2004.02.002

105. M. A. Mofid, A. Abdollah-zadeh and F. Malek Ghaini, The Effect of Water Cooling during Dissimilar Friction Stir Welding of Al Alloy to Mg Alloy, Mater. Des. 36 (2012) 161-167. https://doi.org/10.1016/j.matdes.2011.11.004

106. L. Liu, L. Xiao, D. L. Chen, J. C. Feng, S. Kim and Y. Zhou, Microstructure and Fatigue Properties of Mg-to-Steel Dissimilar Resistance Spot Welds, Mater. Des. 45 (2013) 336-342. https://doi.org/10.1016/j.matdes.2012.08.018

107. C. Tan, X. Song, S. Meng, B. Chen, L. Li and J. Feng, Laser Welding-Brazing of $\mathrm{Mg}$ to Stainless Steel: Joining Characteristics, Interfacial Microstructure, and Mechanical Properties, Int. J. Adv. Manuf. Technol. 86(1-4) (2016) 203-213. https://doi.org/10.1007/s00170-015-8165-0

108. K. Miyamoto, S. Nakagawa, C. Sugi, H. Sakurai and A. Hirose, Dissimilar Joining of Aluminum Alloy and Steel by Resistance Spot Welding, SAE Int. J. Mater. Manuf. 2(1) (2009) 58-67. https://doi.org/10.4271/2009-01-0034

109. H. Kasai, Y. Morisada and H. Fujii, Dissimilar FSW of Immiscible Materials, Steel/Magnesium, Mater. Sci. Eng. A. 624 (2015) 250-255. 
https://doi.org/10.1016/j.msea.2014.11.060

110. V. K. Patel, D. L. Chen and S. D. Bhole, Dissimilar Ultrasonic Spot Welding of $\mathrm{Mg}-\mathrm{Al}$ and $\mathrm{Mg}$-high Strength Low Alloy Steel, Theor. Appl. Mech. Lett. 4(041005) (2014) 1-8 . https://doi.org/10.1063/2.1404105

111. K. V. Kovalan, G. Suriati and N. R. Engineering, A Review of Welding Parameter on Corrosion Behavior of Aluminum, Int. J. Eng. Appl. Sci. 1(1) (2012) 17-22.

112. Y. Shi, J. Li, G. Zhang, J. Huang and Y. Gu, Corrosion Behavior of Aluminum-Steel Weld-Brazing Joint, $J$. Mater. Eng. Perform. 25(5) (2016) 1916-1923. https://doi.org/10.1007/s11665-016-2020-9
113. J. Wloka, H. Laukant, U. Glatzel, and S. Virtanen, Corrosion Properties of Laser Beam Joints of Aluminium with Zinc-coated Steel, Corros. Sci. 49(11) (2007) 4243-4258.

https://doi.org/10.1016/j.corsci.2007.04.014

114. P. Volovitch, T. N. Vu, C. Allély, A. Abdel Aal and K. Ogle, Understanding Corrosion via Corrosion Product Characterization: II. Role of Alloying Elements in Improving the Corrosion Resistance of $\mathrm{Zn}-\mathrm{Al}-\mathrm{Mg}$ Coatings on Steel, Corros. Sci. 53(8) (2011) $2437-$ 2445.

https://doi.org/10.1016/j.corsci.2011.03.016 